\title{
SENI ARSITEKTUR ISLAM MINANGKABAU DARI MASA KE MASA
}

\section{THE ART OF MINANGKABAU ISLAMIC ARCHITECTURE FROM TIME TO TIME}

\author{
Muhammad Husni dan Olvyanda Ariesta \\ Institut Seni Indonesia Padangpanjang \\ J1. Bahder Johan Padangpanjang 27128 Sumatera Barat \\ E-mail : mubarok_hsn@yahoo.com dan olvyandaariesta@isi-padangpanjang.ac.id \\ Naskah diterima 4 Oktober 2018, diterima setelah perbaikan 28 Oktober 2018, \\ disetujui untuk dicetak 28 November 2018
}

\begin{abstract}
Abstrak
Semenjak masuknya Islam ke Minangkabau mulai dari zaman klasik yang bersifat tradisional hingga sekarang corak seni arsitektur Islam Minangkabau berupa surau dan masjid terus berkembang dengan daya tarik tersendiri sehingga menarik untuk dikaji dan diteliti. Penelitian ini mengkaji secara spesifik bentuk atau tipologi atap surau dan masjid di Minangkabau sebagai ciri khas yang paling menonjol pada arsitektur bangunan umat Islam. Penelitian ini bersifat deskriptif-komparatif dengan menggunakan sumber data yang dikumpulkan melalui observasi, wawancara dan studi kepustakaan. Populasi sampel sebagai objek studi dipilih berdasarkan kelompok corak tertentu yang dapat mewakili coraknya. Hasil yang dicapai dari penelitian ini telah menemukan corak arsitektur surau dan masjid di Minangkabau dari zaman klasik sampai sekarang terbagi ke dalam dua tipologi yaitu tipologi atap tumpang dan tipologi atap kubah. Masing-masing dari kedua tipologi itu memiliki sejumlah varian tertentu yang dipengaruhi oleh faktor peradaban Hindu, China, Islam dan adat Minangkabau yang bersifat estetisfilosofis.
\end{abstract}

Kata Kunci: Seni Arsitektur, Islam, Surau, Masjid, Minangkabau

\begin{abstract}
Since the coming of Islam to Minangkabau in the classic era with its traditional characteristics until today, the design of Minangkabau Islamic architecture such as Surau and mosque keeps developing with its own attraction so it's interesting to study further. This research specifically studies the form or typology of Surau and mosque roofs in Minangkabau as the most prominent characteristics in the architecture of M oslem's building. This research is descriptive and comparative research by using the source of data collected through observation, interview and library research. Sample as the object of study was chosen based on the group of certain design that could represent its design. The result of the research is it has been found out the design of architecture surau and mosque in Minangkabau from classic era till right now consist of atap tumpang and atap kubah typology. Both of them have some certain variant that influenced by Hindu, Chinese, Islam and esthetic-philosophical element on Minangkabau culture.
\end{abstract}

Keywords: Architecture Art, Islam, Surau, Mosque, Minangkabau 


\section{PENDAHULUAN}

Indonesia adalah bangsa yang memiliki berbagai macam suku dan budaya. Salah satu hasil kebudayaan tersebut dapat berupa seni arsitektur bangunan rumah ibadahnya. Setiap daerah tentu memiliki ciri khas dan karakter tersendiri pada arsitektur bangunannya. Minangkabau merupakan salah satu suku di Indonesia yang mayoritas penduduknya beragama Islam. Di samping memiliki agama yang kuat, masyarakat Minangkabau juga dikenal sangat keras adatnya. Hubungan Islam dan adat di Minangkabau tergambar dalam pepatahnya "Adat Basandi Syarak, Syarak Basandi Kitabullah (ABS-SBK), Syarak Mangato Adat Mamakai" (Adat bersendi agama, dan agama bersendi kitab Allah, agama memerintahkan dan adat melaksanakan).

Umat Islam di Minangkabau memiliki rumah ibadah yang disebut dengan surau dan masjid. Apabila surau pada awalnya merupakan bangunan pelengkap rumah gadang (rumah adat) maka masjid merupakan sarana yang harus dimiliki sebagai syarat dapat berdirinya sebuah nagari di Minangkabau seperti dalam potongan ungkapan babalai-bamusajik (balai adat dan masjid) (Amir M.S, 2007: 55). Oleh sebab itu, pada setiap nagari dapat ditemukan satu masjid nagari yang dapat menampung masyarakat nagari untuk melaksanakan shalat jumat dan kegiatan keislaman lainnya. Namun seiring dengan perkembangan dan pertambahan jumlah penduduk telah melahirkan sejumlah masjid dalam satu nagari. Selain masjid sebagai pusat ibadah, masyarakat Minangkabau juga mengenal dan memiliki surau (langgar), baik yang dikelola oleh satu suku tertentu maupun yang telah menjadi milik bersama. Kedua bangunan ini memiliki peranan sosial keagamaan bagi masyarakat Minangkabau.

Surau dan masjid adalah dua model bangunan seni arsitektur Islam Minangkabau yang menjadi pusat penyebaran dakwah dan peradaban Islam di Minangkabau. Ditinjau dari segi arsitektur kedua bangunan tersebut, ia merupakan bagian dari seni arsitektur Islam yang memiliki corak, ragam, dan bentuk dengan nilai estetika dan falsafah yang tinggi sebagai warisan kebudayaan Islam Minangkabau dari masa ke masa.

Dalam dunia seni arsitektur kita mengenal berbagai macam corak arsitektur masjid yang sangat terlihat dan menonjol pada gaya atapnya, diantaranya ada yang bercorak Arab, India, Turki, Persia, Indonesia dan Minangkabau. Sebuah karya arsitektur tidak akan pernah lepas dari keadaan masyarakat yang melahirkannya dan alat untuk memahami keadaan masyarakat tempat dimana benda itu berada (Fanani : 2009 : 25). Banyak dan beragamnya corak surau dan masjid di Minangkabau dari masa ke masa semenjak zaman sebelum kemerdekaan dan pasca kemerdekaan sampai saat ini menarik untuk diteliti gaya dan bentuk atapnya sebagai ciri khas arsitektur yang paling menonjol pada sebuah bangunan. Berdasarkan itu dapat dikenal tipologi, karakternya serta faktor yang mempengaruhinya atau filosofinya sekaligus publikasi warisan budaya umat Islam Minangkabau.

Apabila corak atap rumah adat Minangkabau telah diteliti dan dikaji bahkan memperbandingkan corak rumah adat yang ada di Minangkabau, maka dalam hal ini belum ditemukan penelitian secara khusus tentang corak atap surau dan masjid yang terus tumbuh dan berkembang di Minangkabau. Kajian tentang surau dan masjid lebih cenderung menekankan pada satu surau atau masjid tertentu dalam berbagai macam aspek bahkan lebih cenderung mengedepankan aspek kesejarahannya. Surau dan masjid adalah bentuk hasil karya arsitektur Islam Minangkabau dengan ciri khas tersendiri yang terus tumbuh dan berkembang dari masa 
ke masa. Hal ini merupakan wujud dari budaya dan peradaban umat Islam Minangkabau sekaligus bukti sejarah Islam yang menyisihkan banyak nilai dan pelajaran bagi generasi sesudahnya.

\section{METODE PENELITIAN}

Penelitian ini bersifat deskriptif-komparatif yaitu pemaparan secara komprehensif terhadap corak dan struktur atap surau dan masjid sebagai bagian dari seni arsitektur Islam Minangkabau. Seluruh corak atau gaya atap surau dan masjid yang ada di Minangkabau dihimpun dan diidentifikasi untuk menentukan karakter dan tipologinya. Kemudian semua corak yang terdapat dalam satu tipologi dikomparasi satu sama lain sehingga tampak perbedaan masingmasing corak tersebut. Bentuk atau corak surau dan masjid diambil melalui pemotretan langsung di lokasi terhadap sejumlah surau dan masjid yang dapat mewakili corak tertentu. Keterangan tentang bentuk surau dan masjid dihimpun melalui hasil wawancara yang dilakukan baik di lokasi saat pemotretan maupun di tempat lain dengan orang yang dianggap layak untuk dimintai keterangannya. Di samping itu data juga dihimpun berdasarkan literatur-literatur yang memiliki kaitan dengan penelitian ini seperti buku, jurnal dan artikel baik online maupun offline.

Metode pengumpulan data dilakukan dengan tiga metode yaitu observasi, wawancara dan kajian pustaka. Seluruh data yang telah terkumpul dianalisis berdasarkan persamaanpersamaan maupun perbedaan-perbedaan diantara corak atap surau dan masjid yang ada di Minangkabau dalam satu tipologi yang sama. Populasi sampel diambil dan dipilih menurut corak yang dapat mewakili jenisnya yang dapat ditemukan sampai sekarang. Berdasarkan hasil penelitian ini telah dapat mengungkap corak, karakter dan tipologi seni arsitektur Islam Minangkabau berupa surau dan masjid dari zaman klasik yang bersifat tradisional hingga saat ini yang telah maju dan canggih.

\section{PEMBAHASAN}

\section{Minangkabau dan Islam}

Daerah Minangkabau sering diidentikkan dengan daerah yang berada dalam kawasan Propinsi Sumatera Barat saat ini. Bergantinya sebutan Minangkabau menjadi Sumatera Barat berawal dari penyebutan Residentie van Sumatera Westkust yang dilakukan oleh kolonial Belanda dalam memetakan daerah jajahannya (Samad, 2002 : 2). Kemudian penamaan ini terus digunakan pada masa kemerdekaan Indonesia. Pada masa orde lama, kawasan wilayah Minangkabau yang sebagian besar itu berada pada kawasan Sumatera Tengah (Sumatera Barat, Riau dan Jambi sekarang), semenjak terjadi peristiwa PRRI yang berpusat di Sumatera Barat sekarang, maka Propinsi Sumatera Tengah yang dahulu terdiri dari Riau, Jambi dan Sumatera Barat dipecah oleh Sukarno menjadi tiga propinsi. Semenjak itu, kawasan Minangkabau yang memang sebagian besar wilayahnya berada dalam kawasan Propinsi Sumatera Barat sekarang menyebabkan Minangkabau sering diidentikkan dengan Sumatera Barat dan demikian juga sebaliknya sebutan Sumatera Barat sering diidentikkan dengan Minangkabau.

Keberadaan orang Minangkabau yang berada di luar kawasan Sumatera Barat menyebabkan mereka terdesak oleh kebudayaan yang menguasai di propinsi mana ia berada seperti di Propinsi Riau yang memberlakukan kantor pemerintahan mesti menggunakan relif rumah adat Melayu Riau meskipun penduduk asal dan budayanya adalah orang Minangkabau 
(Suku Limo Koto; Bangkinang, Aia Tirih, Kuok dan Kampar yang merupakan bagian dari Luhak Lima Puluh Kota). Dengan demikian secara berangsur-angsur terjadi penyempitan daerah Minangkabau.

Untuk melestarikan kebudayaan Minangkabau maka pemerintah Propinsi Sumatera Barat juga mewajibkan gedung-gedung pemerintahan dan perkantoran mesti memiliki ciri khas Minangkabau yaitu bagonjong seperti atap rumah adatnya (Indrayuda, 2013: 7-8). Persoalan politik pemerintahan yang terjadi di Indonesia menyebabkan daerah bekas kawasan teritorial suatu suku bangsa tidak mutlak menjadi kawasan teritorial suatu pemerintahan seperti yang berlaku dan terjadi pada Propinsi Sumatera Barat yang tidak hanya masyarakat asli Minangkabau maupun yang berlaku bagi masyarakat Minangkabau di luar Propinsi Sumatera Barat.

Kawasan Minangkabau memiliki dua makna yaitu kawasan Minangkabau secara adat dan budaya dan kawasan Minangkabau dalam artian wilayah secara administratif. Tidak semua kawasan Minangkabau saat ini secara adat dan budaya berada dalam teritorial pemerintahan dan administratif yang sama. Bahkan wilayah atau daerah teritorial Minangkabau sebelum masa penjajahan dan sebelum kemerdekaan jauh lebih luas dari sebutan Sumatera Barat setelah masa kolonial dan kemerdekaan maupun sebagai salah satu propinsi saat ini. Batas wilayah Minangkabau yang termasuk ke dalam Propinsi Sumatera Barat saat ini yaitu sebelah barat berbatasan dengan Samudera Indonesia, sebelah utara berbatasan dengan Sumatera Utara, sebelah selatan berbatasan dengan Propinsi Bengkulu dan Propinsi Jambi, dan sebelah timur berbatasan dengan Propinsi Riau.

Sumatera Barat terdiri dari 12 kabupaten dan 7 kota antara lain; Kabupaten Tanah Datar, Kabupaten Agam, Kabupaten Lima Puluh Kota, Kabupaten Pasaman, Kabupaten Pasaman Barat, Kabupaten Padang Pariaman, Kabupaten Pesisir Selatan, Kabupaten Sijunjung, Kabupaten Solok, Kabupaten Solok Selatan, Kabupaten Dharmasraya, Kabupaten Kepulauan Mentawai, Kota Bukittinggi, Kota Padang, Kota Padang Panjang, Kota Pariaman, Kota Payakumbuh, Kota Sawahlunto, dan Kota Solok. Oleh sebab itu, banyaknya daerah basis Minangkabau tempo dulu berada dalam wilayah Propinsi Sumatera Barat pada masa sekarang menyebabkan yang dikenal dengan daerah Minangkabau tersebut adalah yang berada dalam wilayah Propinsi Sumatera Barat saat ini.

Propinsi Sumatera Barat hanya satu kabupaten yang merupakan bukan tempat asal peradaban suku Minangkabau yaitu Kabupaten Kepulauan Mentawai, sedangkan satu kabupaten lain yaitu Pasaman Barat merupakan percampuran dua etnis yaitu Minangkabau dengan Mandailing. Selain dari dua daerah tersebut selebihnya merupakan kawasan asal dan rantau suku Minangkabau (Indrayuda, 2013: 8-11). Sumatera Barat merupakan basis terbesar daerah pemukiman dan peradaban suku Minangkabau masa kini. Oleh sebab itu kata Minangkabau dalam penelitian ini mengacu kepada wilayah yang berada dalam propinsi Sumatera Barat secara teritorial, bukan Minangkabau secara adat dan budaya.

Adapun agama yang dianut oleh masyarakat Minangkabau asli adalah agama Islam sehingga dikatakan "tidak Minang bila tidak Islam”. Tidak didapat keterangan yang pasti tentang sejak kapan atau awal masuk Islam ke Minangkabau. Diantara pendapat yang ada dikatakan bahwa Islam sudah masuk ke Minangkabau sejak abad-adab awal hijriyah yaitu sejak abad ke7 atau ke-8 H karena Minangkabau timur merupakan jalur perdagangan penting menuju Malaka. Jalur perdagangan lebih mudah ditempuh melalui sungai-sungai terutama melalui Sungai Kampar Kanan 
dan Kampar Kiri yang bermuara di Selat Malaka. Di samping berdagang, para saudagar muslim itu juga menyampaikan dan menyebarkan Islam.

Dalam pendapat lain dinyatakan bahwa Islam masuk ke Minangkabau pada abad ke-13 melalui Syekh Burhanuddin al-Kamil Kuntu, Kampar ( Firdaus, 2014 : 15-18) sehingga setelah masuknya Islam semenjak itu, masyarakat Minangkabau beralih memeluk agama Islam hingga Kerajaan Pagaruyung yang bercorak Hindu Jawa sebagai pusat Kerajaan Minangkabau secara berangsur-angsur telah dipengaruhi oleh Islam.

Dalam pendapat lain disederhanakan bahwa Islam masuk ke Minangkabau melalui dua jalur. Pertama melalui jalur Pesisir Timur (Selat Malaka) melalui Rantau Kuantan, Kampar, Siak dan Indragiri. Kedua dengan Pesisir Barat (Samudra India) melalui Bandar-bandar lama seperti Tiku dan Pariaman. Selanjutnya agama Islam dari Pesisir Timur (daerah rantau) dan daerah Pesisir Barat bertemu di daerah Minangkabau asli. Inilah mungkin yang dimaksud pepatah syara' mendaki, adat menurun yang artinya adat turun ke daerah rantau (Pesisir) dan syara' (hukum agama) mendaki ke darek (wilayah asal nenek moyang Minangkabau). (Alimin : 2016 : 82)

Masyarakat Minangkabau dapat dengan cepat menerima ajaran Islam karena telah memiliki peradaban yang banyak bersesuaian dengan ajaran Islam. Kuatnya pengaruh Islam sehingga yang dulunya falsafah adat basandi alua jo patuik, alua jo patuik basandi ka nan bana, nan bana badiri sendirinyo berubah menjadi adat basandi syarak, syarak basandi kitabullah, syarak mangato adat mamakai (Indrayuda: 2013: 7-8). Islam telah mempengaruhi berbagai sisi kehidupan manusia dalam membentuk kebudayan dan peradaban masyarakat Minangkabau yang diantaranya terlihat dalam seni arsitekturnya.

\section{Surau dan Masjid di Minangkabau}

Surau adalah kata yang sudah tersebar di Asia Tenggara, secara turun temurun. Istilah ini tampaknya telah digunakan secara meluas di Minangkabau, Tanah Batak, Sumatera Tengah, Sumatera Selatan, Semenanjung Malaya dan Patani (Thailand Selatan) dalam arti yang sama. Secara bahasa kata surau berarti tempat atau tempat ibadah (Hanani, 2002 : 63-64). Menurut Sidi Gazalba surau merupakan bangunan peninggalan kebudayaan masyarakat Minangkabau sebelum datangnya Islam. Surau merupakan bangunan yang dibangun oleh suatu kaum sebagai pelengkap dari rumah gadang. Sebelum Islam datang, surau dimaksudkan berfungsi sebagai tempat bertamu, berkumpul, rapat dan tempat tidur bagi anak laki-laki yang telah akil balig dan orang tua yang telah uzur. Fungsi ini berkaitan dengan ketentuan adat bahwa anak laki-laki tidak mempunyai kamar di rumah gadang dan di rumah orang tuanya sendiri, dan yang memiliki kamar di rumah orang tuanya sendiri hanyalah anak-anak perempuan. Sedangkan bagi kaum lelaki harus meninggalkan rumahnya karena anak gadis di rumah itu telah menikah sehingga ia harus kembali ke lingkungan kaumnya sehingga laki-laki itu tidurnya di surau (Azra, $2003: 7-8$ ).

Masuknya Islam ke Minangkabau, surau turut mengalami islamisasi. Fungsinya sebagai tempat menginap bagi anak bujang tidak berubah namun fungsinya diperluas menjadi tempat pengajaran, pengembangan ajaran Islam dan tempat shalat dan belajar al-Quran. Dalam perkembangan selanjutnya terjadi pemisahan yang cukup jelas antara fungsi masjid dan surau. Masjid lebih difungsikan untuk kepentingan ibadah dalam pengertian sempit yaitu shalat berjamaah seperti shalat fardu, jumat dan 
hari raya. Sedangkan surau semakin luas fungsinya, selain menjadi asrama bagi anak laki-laki ia juga menjadi tempat belajar mengaji, belajar agama, kegiatan kegaamaan, tempat suluk, tempat berkumpul, rapat, menginap musafir, berkesenian dan sebagainya. Bahkan masing-masing buya atau ulama dalam menyebarkan Islam memiliki surau dan mendirikan surau masing-masing dengan muridnya yang datang dari berbagai daerah. Surau merupakan semacam masjid dalam ukuran lebih kecil.

Adapun masjid, dari segi bahasa kata masjid berasal dari bahasa Arab yang terambil dari akar kata sajada-sujud, yang berarti patuh, taat, serta tunduk dengan penuh hormat dan takzhim. Oleh karena itu, meletakkan dahi, kedua tangan, lutut, dan kaki ke bumi, dalam syariat Islam dinamai sujud karena merupakan bentuk lahiriah yang paling nyata dari makna-makna di atas. Itulah sebabnya mengapa bangunan yang dikhususkan untuk melaksanakan shalat yang didalamnya terdapat sujud dinamakan masjid, yang artinya "tempat bersujud”' (Shihab, 2000 : 459). Dalam al-Qur'an, Allah swt menegaskan bahwa, "Sesungguhnya masjid-masjid itu adalah milik Allah, karena itu janganlah menyembah selain Allah sesuatu pun." (Q.S al-Jin (72): 18)

Dalam pengertian sehari-hari, masjid merupakan bangunan tempat shalat umat Islam. Pemilihan masjid untuk menyebut tempat shalat adalah karena sujud merupakan perbuatan paling mulia untuk mendekatkan diri kepada sang pencipta. Masjid sebagai tempat yang disiapkan untuk shalat secara khusus yang ukurannya dapat menampung banyak jamaah dan dapat dilaksanakannya shalat jumat serta berlaku permanen tidak hanya untuk sementara, maka lapangan tidak dikategorikan sebagai masjid dalam artian khusus. Selain masjid terdapat juga sebutan lain yang mengandung arti yang sama yaitu jamik. Penyebutannya terkadang digabung dan terkadang terpisah. Istilah jamik mengandung makna "mengumpulkan" atau "menghimpun" yang mana jamik merupakan sifat dari masjid karena memang masjid dapat mengumpulkan dan menghimpun jamaah (Husain, 2011: 12-13) sehingga terkadang disebut masjid jamik. Surau dan masjid memiliki kedudukan dan peranan yang sangat penting di Minangkabau. Ia tidak hanya sebagai tempat pusat peribadatan tapi juga merupakan bagian dari budaya dan peradaban umat Islam yang memiliki berbagai macam corak seni arsitekturnya.

\section{Seni Arsitektur Islam Minangkabau}

Islam telah berkembang sejak 14 abad silam dan selama itu pula Islam turut mewarnai sejarah kehidupan umat manusia dalam berbagai bidang termasuk bidang sosial, budaya dan peradaban manusia antara lain dalam bentuk karya arsitektur. Tempat ibadah umat Islam merupakan salah satu bentuk wujud nyata yang paling menonjol dari arsitektur Islam. Peninggalan arsitektur Islam tak hanya di Jazirah Arab, tapi menyebar ke berbagai belahan dunia dan berpadu dengan budaya setempat. Puncak peradaban suatu bangsa menurut Ibnu Khaldun ditandai oleh karya arsitekturnya. Kemal Schoemaker meyakini bahwa arsitektur adalah buah refleksi potensi rohani yang hidup di tengah masyarakat. Tidak ada perwujudan karya yang lebih jelas menggambarkan situasi kebudayaan suatu kelompok masyarakat bahkan sampai ke pandangan hidup dan cita-cita keyakinannya kecuali arsitektur. (Fanani : 2009 : 17-18).

Dalam masyarakat Minangkabau terdapat dua tempat ibadah yang sangat popouler di tengah masyarakatnya yaitu surau dan masjid. Surau dan masjid memiliki kedudukan tersendiri dalam kehidupan sosial keagamaan di Minangkabau. Surau yang pada awalnya merupakan bangunan yang dibangun oleh suatu kaum sebagai pelengkap dari rumah gadang (rumah adat) berkembang menjadi pusat 
ibadah dan penyebaran Islam di Minangkabau, sebagaimana halnya masjid sebagai kelengkapan sebuah nagari demi tegaknya syi' ar Islam dalam masyarakat Minangkabau (Azra, 2003: 3-8).

Beragam bentuk dan corak arsitektur surau dan masjid di Minangkabau yang terkadang berbeda dari zaman dengan zaman berikutnya meskipun ada juga yang mengadopsi gaya arsitektur sebelumnya. Munculnya berbagai macam corak dan ragam seni arsitektur surau dan masjid di Minangkabau dari masa ke masa tak terlepas dari pengaruh budaya, pengetahuan dan pemikiran manusia yang berkembang dan diiringi dengan kemajuan teknologi yang semakin canggih sehingga beragam inovasi mewarnai arsitektur tempat ibadah umat Islam tersebut. Kenyataannya dalam Islam memang tidak ada bentuk baku yang mengatur corak ragam seni arsitektur rumah ibadah itu sendiri.

Tidak dapat diketahui secara pasti tentang sejak kapan Islam masuk ke Minangkabau, maka masjid ataupun surau pertama pun tidak diketahui bentuknya. Oleh karena itu, arsitektur surau dan masjid yang dimaksudkan dalam penelitian ini adalah yang masih dapat dijumpai hingga saat ini. Berdasarkan pengamatan dan penelitian yang dilaksanakan maka ditemukan beberapa tipologi atau corak atap seni arsitektur surau dan masjid di Minangkabau dari masa ke masa semenjak zaman klasik hingga saat ini sebagai berikut:

\section{Tipologi Atap Tumpang}

Keberadaan peradaban Hindu di Minangkabau sangat mempengaruhi corak atau gaya aristektur surau dan masjid. Surau dan masjid zaman awal perkembangan Islam di Minangkabau memiliki ciri khas atap tumpang yang berbentuk limas yang semakin ke atas semakin kecil dan mengerucut. Jumlah atap tumpang ini biasanya terdiri dari tiga atau lima tingkatan. Gaya arsitektur ini merupakan karakter atau ciri khas surau dan masjid pada zaman klasik yang masih bersifat tradisional. Corak atau gaya arsitektur ini dikenal juga dengan arsitektur vernakular (gaya arsitektur yang dirancang berdasarkan kebutuhan lokal, ketersediaan bahan bangunan dan mencerminkan tradisi lokal atau struktur yang dibuat oleh masyarakat lokal tanpa intervensi dari arsitek profesional, ia bergantung pada kemampuan desain dan tradisi pembangunan lokal, arsitektur yang tumbuh dan berkembang dari arsitektur rakyat yang lahir dari masyarakat etnik).

Di samping beratap tumpang, ia dibangun di atas pondasi berbentuk bujur sangkar. Corak ini pada umumnya ditemukan pada surau atau masjid tua yang memiliki nilai sejarah zaman klasik dan merupakan bentuk masjid generasi zaman awal perkembangan Islam di Minangkabau. Tidak hanya di Minangkabau tetapi seluruh masjid yang ada di Indonesia pada umumnya mengambil bentuk ini sebagai corak awal masjid di nusantara seperti pada masjid Agung Demak dan Masjid Agung Banten.

Meskipun corak awal arsitektur surau dan masjid di Minangkabau pada umumnya mirip dan hampir sama dengan masjid Demak dan masjid-masjid yang ada di Pulau Jawa maupun daerah lainnya sebagai bentuk perkembangan awal masjid-masjid di nusantara, namun nilai-nilai budaya lokal (local genius/kearifan lokal) yang hidup di tengah masyarakat ikut mempengaruhinya. Bentuk arsitektur masjid dan surau tradisional di Minangkabau ini juga dipengaruhi oleh keberadaan adat Minangkabau yang memiliki dua kelarasan dalam sistim kepemimpinan di Minangkabau yaitu Koto Piliang dan Bodi Caniago. Masing-masing dari kelarasan ini memiliki bentuk dan gaya arsitektur masjid tersendiri. (Hasan, 2004: 65) 
Pertama, Masjid Kelarasan Bodi Caniago berbentuk bujur sangkar dengan atap tumpang tiga atau lima seperti limas yang semakin ke atas semakin mengerucut namun pada puncaknya seperti selinder yang runcing pada bagian ujungnya (Hasan, 2004: 65-66). Tipologi ini juga merefleksikan sistim pemerintahan Kelarasan Bodi Caniago "membasuik dari bumi" bahwa dalam musyawarah kaum, kata akhir berada di kemanakan, suara rakyat yang paling menentukan. Masjid dengan tipologi ini dapat ditemukan pada masjid-masjid tua di Minangkabau seperti Masjid Raya Lima Kaum (dibangun tahun 1650-1710 M) dan Masjid Raya Bingkudu IV Angkek Canduang Kabupaten Agam (didirikan tahun1823 M ).

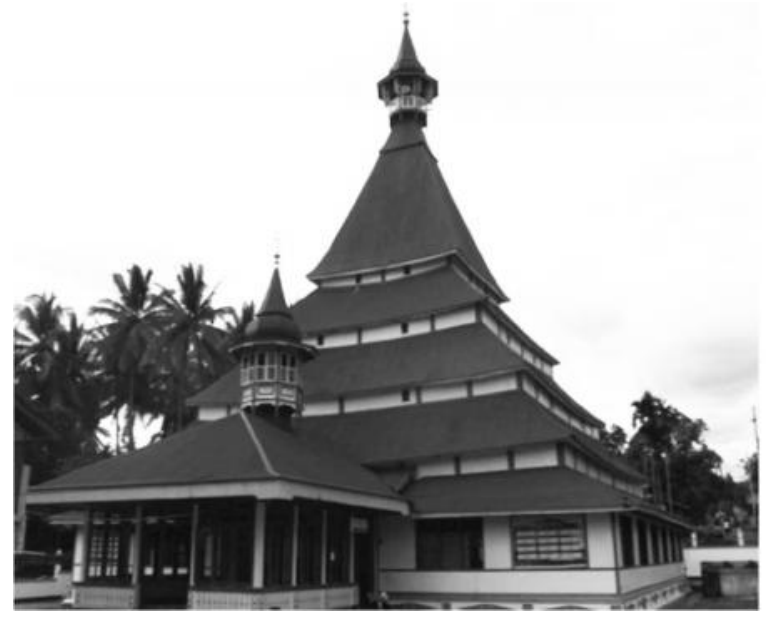

Gambar. 1

Masjid Raya Lima Kaum

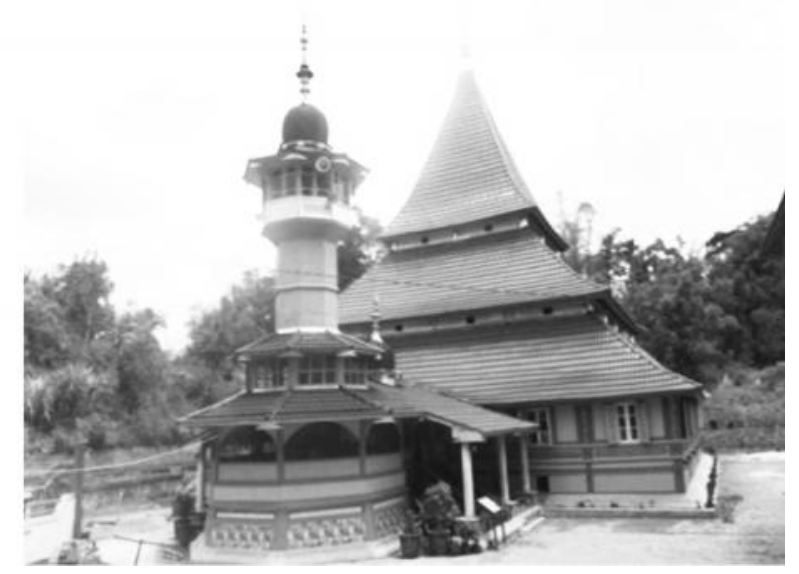

Gambar. 2

Masjid Raya Bingkudu, Canduang

Masjid Raya Lima Kaum memiliki atap tumpang lima yang melambangkan bahwa masjid ini didirikan oleh lima kaum yang terdiri dari lima jorong atau lima desa yaitu Dusun Tuo, Balai Labuah, Piliang, Kuburajo, dan Balai Batu, selain itu juga dikaitkan sebagai perlambangan shalat yang lima waktu (Zainuddin, 2013: 371 - 404). Masjid ini berdiri di atas tanah yang dahulunya merupakan bekas sebuah pagoda atau bangunan agama Hindu yang telah ditinggalkan penganutnya karena sudah masuk Islam karena memang Minangkabau sebelum Islam datang, masyarakatnya menganut peradaban Hindu sehingga berpengaruh terhadap bentuk rumah ibadah yang diislamisasi saat itu.

Selain beratap tumpang lima, pada umumnya masjid bercorak Kelarasan Bodi Caniago ini memiliki atap tumpang tiga seperti Masjid Raya Bingkudu yang memiliki filosofi konsep kepemimpinan di Minangkabau yakni "Tigo Tungku Sjarangan" yang terdri dari "Niniak Mamak, Alim Ulama dan Cadiak Pandai" serta yang dilakukan oleh manusia mesti mengerucut kepada satu titik puncak yaitu keridhaan Allah SWT Yang Maha Tinggi.

Selain pemaknaan di atas, atap tumpang tiga terkadang dimaknai sebagai lambang dari imam, khatib, dan bilal sebagai unsur terpenting terlaksananya shalat Jumat. Diantara masjid-masjid tua atau kuno pada umumnya memiliki corak dan tipologi ini dan masih banyak dapat ditemukan hingga saat sekarang antara lain Masjid Tuo Ishlah Nagari Pariangan Kabupaten Tanah Datar (dibangun pertama kali pada abad ke-11M), Masjid Gadang Balai Nan Duo Koto Nan Ampek, Payakumbuh (tahun 1840), Masjid Pincuran Gadang Matur Kabupateb Agam (tahun 1885 M), Masjid Jamik Taluk Banuhampu (tahun 1870 M ), (lihat gambar 3,4,5,6), Masjid Kurang Aso 60 Nagari Pasir Talang, 
Kecamatan Sungai Pagu, Kabupaten Solok Selatan (didirikan sebelum tahun 1733 M). Pada awalnya masjid-masjid ini beratap ijuk namun secara perlahan dari waktu ke waktu berubah atap seng.

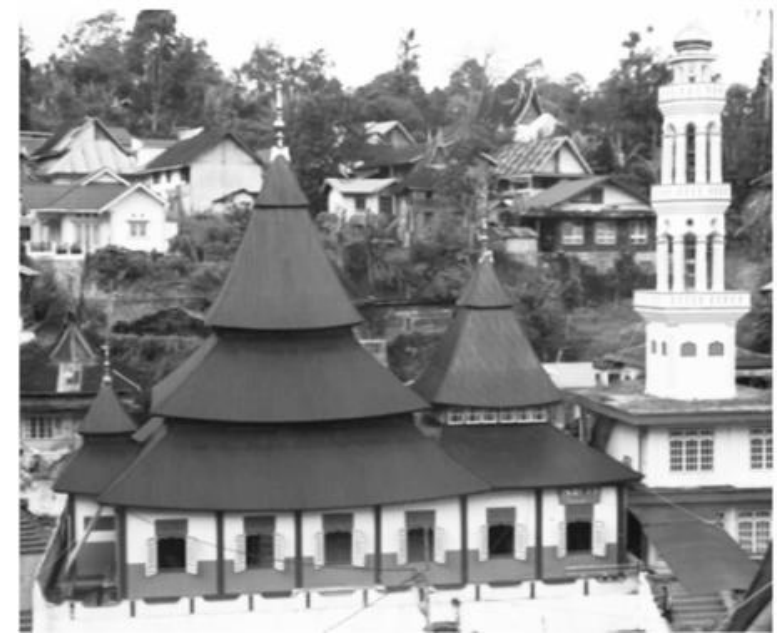

Gambar. 3

Masjid Tuo Ishlah Pariangan

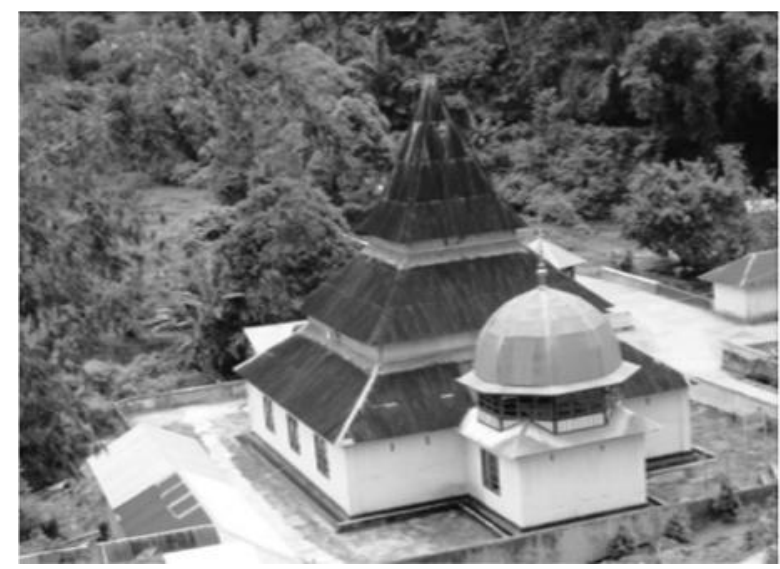

Gambar. 5

Masjid Pincuran Gadang Matur

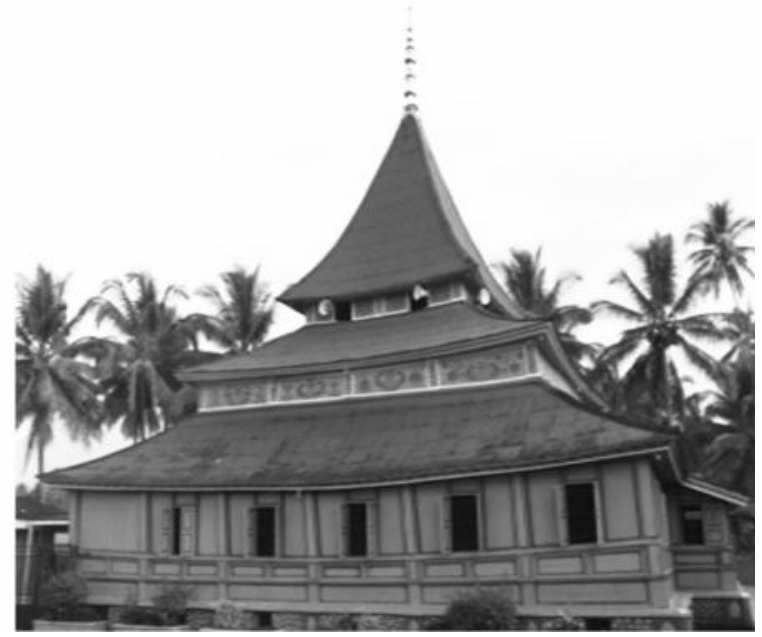

Gambar. 4

Masjid Gadang Balai Nan Duo

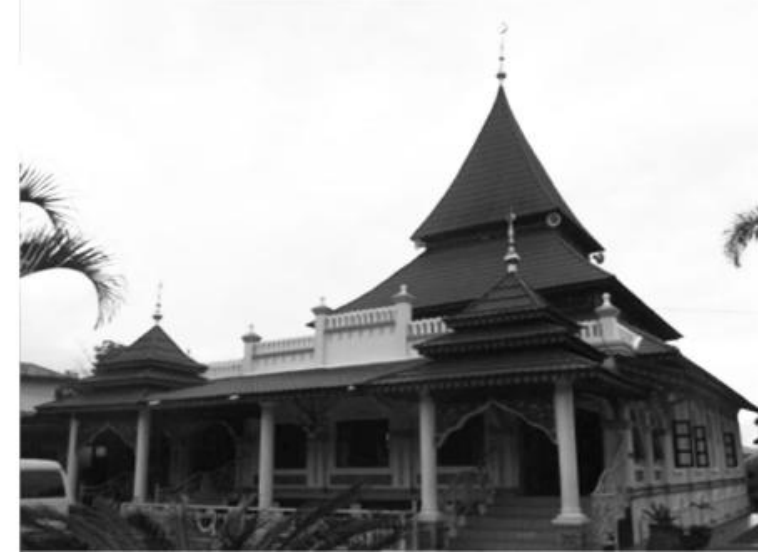

Gambar. 6

Masjid Jamik Taluk Banuhampu

Kedua, Masjid Kelarasan Koto Piliang berbentuk limas yang memiliki atap tumpang berjumlah tiga atau lima dan di puncak atap tersebut terdapat seperti gonjong rumah adat pada keempat sisinya. Tipe masjid kelarasan Koto Piliang, memiliki ciri khas arsitektur yang mengkombinasikan arsitektur Rumah Gadang (rumah adat) di Minangkabau berupa atap bergonjong pada atap bagian puncak (Hasan, 2004: 65-66). Tipologi ini juga merefleksikan sistim atau bentuk pemerintahan Koto Piliang yang bersifat aristokrasi yang disebut "titiek dari ateh" , bahwa untuk mengambil suatu keputusan atau kata akhir berada di tangan kepala suku atau penghulu. Tipologi masjid ini dapat terlihat pada Masjid Raya Rao-Rao Sungai Tarab, Kabupaten Tanah Datar (didirikan tahun 1892-1916).

Tipologi atap tumpang pada umumnya terdiri dari tiga lapis atap utama dan satu atap penutup bagian puncak. Pada atap puncak Masjid Rao-Rao memiliki atap gonjong seperti atap gonjong rumah gadang ciri khas Minangkabau sebanyak empat buah yang mengarah pada empat penjuru mata angin sebagai lambang empat suku di Nagari Rao-Rao yaitu suku Bodi Caniago, Bendang Mandailing, Koto Piliang dan Petapang Koto Anyia. 


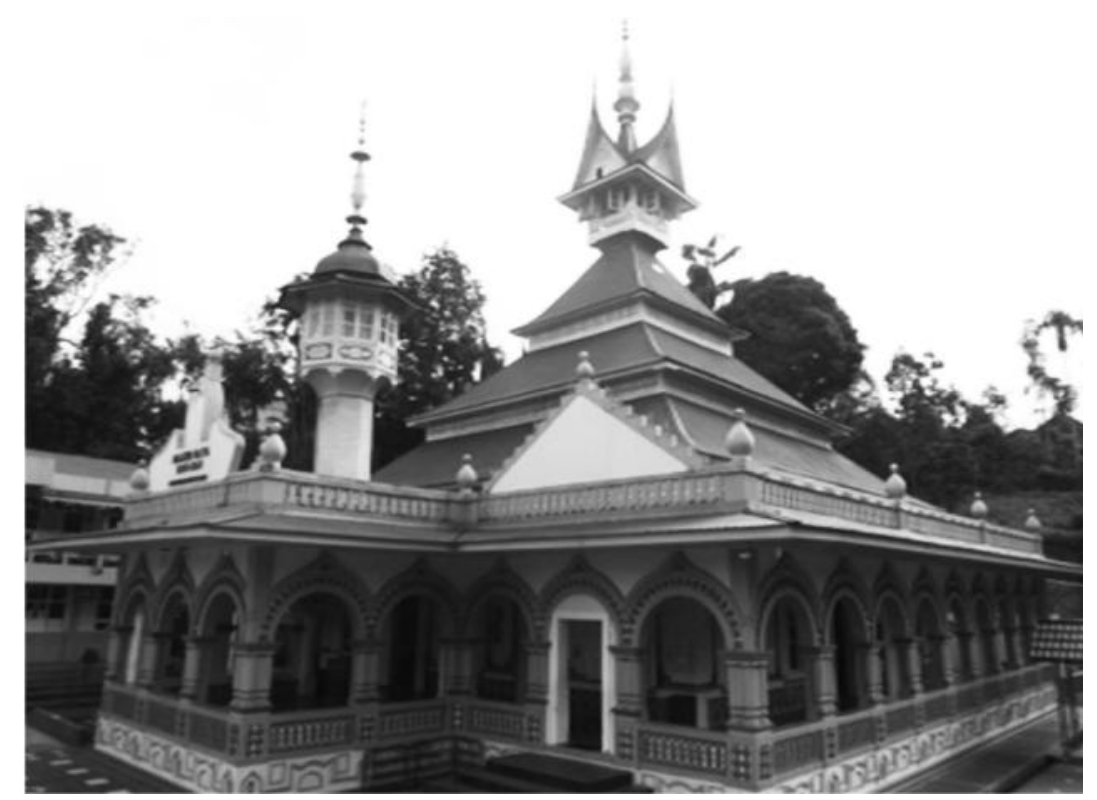

Gambar. 7

Masjid Raya Rao-Rao Sungai Tarab

Selain Masjid Raya Rao-Rao tersebut terdapat masjid lain yang memiliki bentuk arsitektur hampir sama dengan Masjid Rao-Rao yaitu Masjid Sa'adah, Gurun Sungai Tarab Kabupaten Tanah Datar (dibangun tahun 1910-1917) dan Masjid Raya Kotobaru Kabupaten Solok Selatan (dibangun tahun 1922-1933) yang memiliki bentuk arsitektur atap sama dengan Masjid Rao-Rao (lihat gambar. $8,9)$.

Konon kedua masjid tersebut dibangun oleh arsitek/ tukang yang sama, namun atap pada Masjid Sa' adah memiliki tumpang bersusun lima yang menurut masyarakat setempat sebagai bentuk perlambangan lima suku pada waktu itu, yaitu Koto, Piliang, Bendang, Koto Anyiah, dan Pitopang. Adapun empat atap bergonjong pada Masjid Raya Kotobaru mengarah ke empat penjuru mata angin yang dilengkapi dengan mustaka di bagian tengahnya, menurut pemuka masyarakat setempat, empat gonjong melambangkan empat raja dari empat suku yang bermukim di kawasan Alam Surambi Sungai Pagu, yaitu Malayu, Kampai, Panai, dan Tigo Lareh, sementara mustaka yang menjulang setinggi lebih kurang 1,5 meter merupakan perlambangan bahwa empat raja tersebut bertuhan kepada Allah swt tuhan yang satu. Kemudian Masjid Raya Kotobaru ini memiliki dua menara yang berada di sisi kiri dan kanan berupa kubah pada bagian puncaknya, sedangkan Masjid Rao-Rao dan Masjid Sa'adah Gurun hanya memiliki satu menara yang berada ditengah bagian depan masjid namun pada bagian puncaknya tidak pakai kubah seperti Masjid Rao-Rao tetapi empat atap bergonjong.

Selain masjid, terdapat satu surau yang memiliki corak atap tumpang yang bergonjong empat pada puncaknya yaitu Surau Tuo Lubuk Bauk Batipuh Kabupaten Tanah Datar (didirikan tahun 18961901M) (lihat gambar 10). Hal ini melambangkan suku yang membangun surau tersebut yaitu Suku Pisang, Suku Koto, Suku Panyalai, dan Suku Sikumbang. Atap surau ini bersusun tiga, atap pertama dan kedua berbentuk limas, sedangkan atap ketiga yang juga berfungsi sebagai menara memiliki bentuk gonjong di keempat sisinya. Pada bagian puncak, atapnya membentuk kerucut dengan bentuk susunan buah labu/bola-bola kubah/menara yang terletak di atas atap gonjong berbentuk segi delapan. 
Menurut keterangan masyarakat setempat, empat serambi melambangkan Jurai nan Ampek Suku, dan lambang dari empat tokoh pemerintahan (Basa Empat Balai) kerajaan Pagaruyung.

Seni arsitektur masjid tipologi atap tumpang yang bercorak Kelarasan Koto Piliang ini memang sangat unik dan indah sehingga corak ini masih ada yang mempertahankan dalam membangun atau mendirikan masjid baru di zaman modern dengan melakukan beberapa modifikasi seperti yang ada pada masjid al-Azhar kampus ISI Padangpanjang (lihat gambar 11). Menurut salah seorang tokoh masyarakat sekaligus pengurus masjid, Arzul Jama'an (65 tahun) saat diwawancarai menuturkan bahwa atap empat bergonjong tersebut adalah simbol dari imam mazhab yang ada dalam Islam, sedangkan mustika pada bagian tengah yang menjulang ke langit merupakan perlambangan dari ibadah mesti tertuju kepada Tuhan Yang Maha Esa.

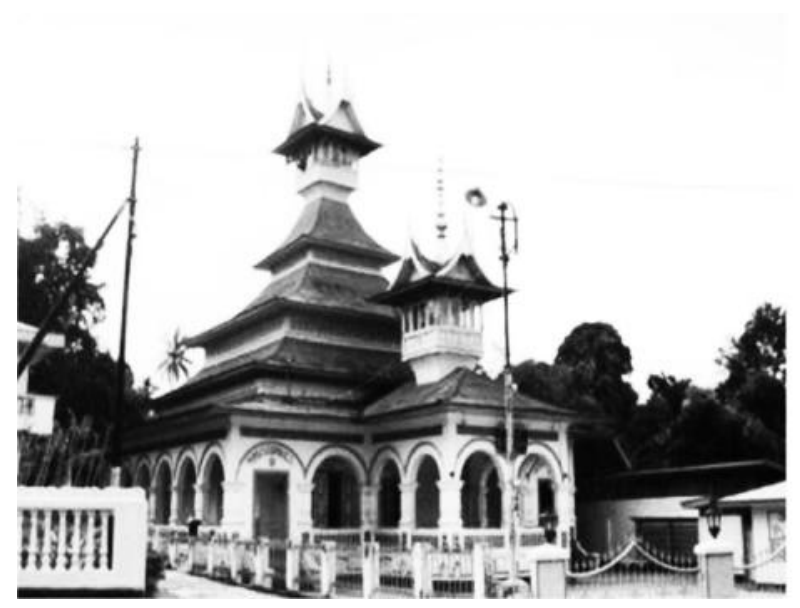

Gambar. 8

Masjid Sa'adah Gurun Sei Tarab

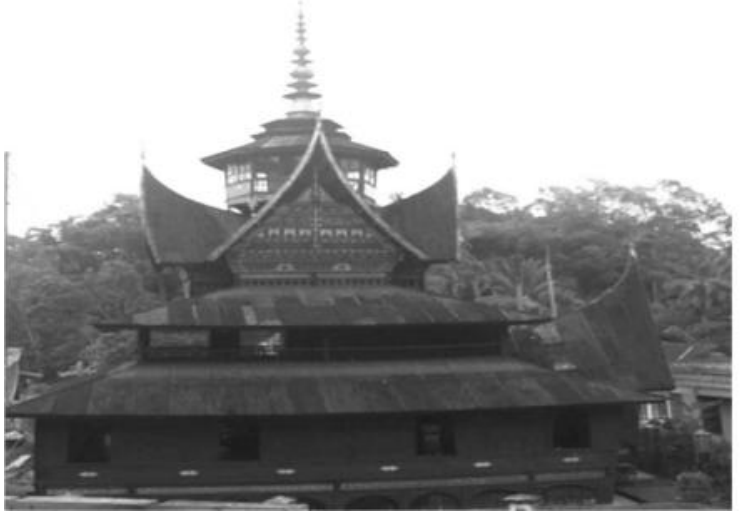

Gambar. 10

Surau Tuo Lubuk Bauk Batipuh

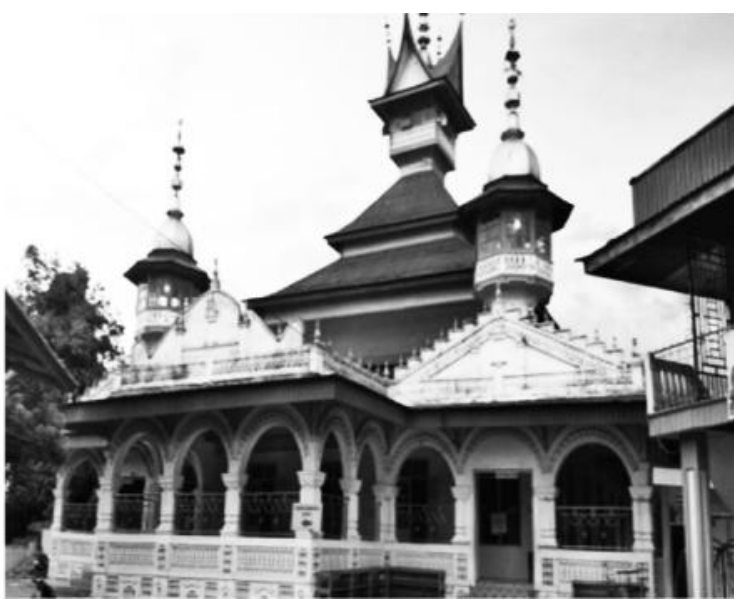

Gambar. 9

Masjid Raya Kotobaru Solsel

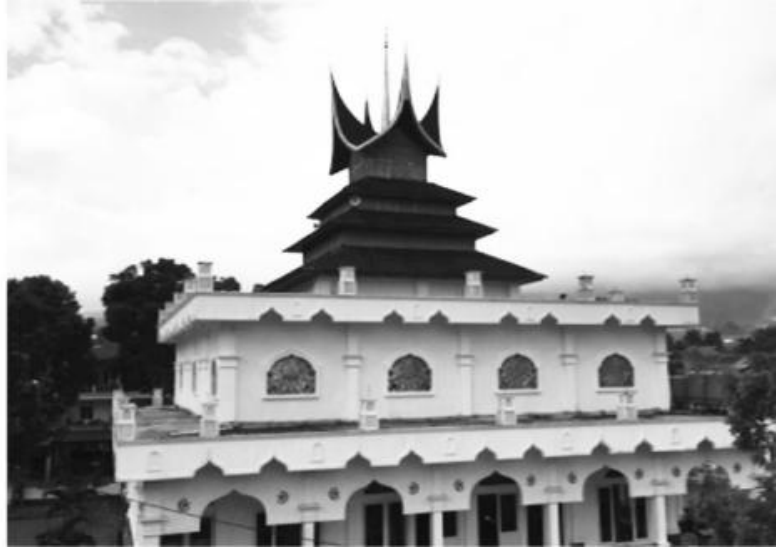

Gambar. 11

Masjid al-Azhar ISI Padangpanjang

Selain dari kedua tipologi diatas terdapat satu corak arsitektur masjid atau surau di Minangkabau sebagai bentuk pengaruh atau perpaduan adat dan Islam di Minangkabau. Perpaduan adat dan Islam itu telah menjadi falsafah Minangkabau yang dinyatakan dalam pepatahnya : Adat Basandi Syarak, Syarak Basandi Kitabullah, Syarak Mangato Adat Mamakai. Hal ini diwukjudkan dalam konsep rumah ibadah dengan cara membentuk atapnya berupa atap bergonjong seperti pada atap rumah 
gadang. Corak ini tidak seperti pada masjid kelarasan Koto Piliang tetapi atap bergonjong dibuat pada bagian mihrabnya atau pada bagian pintu masuknya. Gaya arsitektur yang memadukan antara atap tumpang dengan gaya atap rumah gadang pada bagian mihrabnya dapat ditemukan pada Masjid Tuo Kayu Jao Kabupaten Solok (didirikan tahun 1599 M).

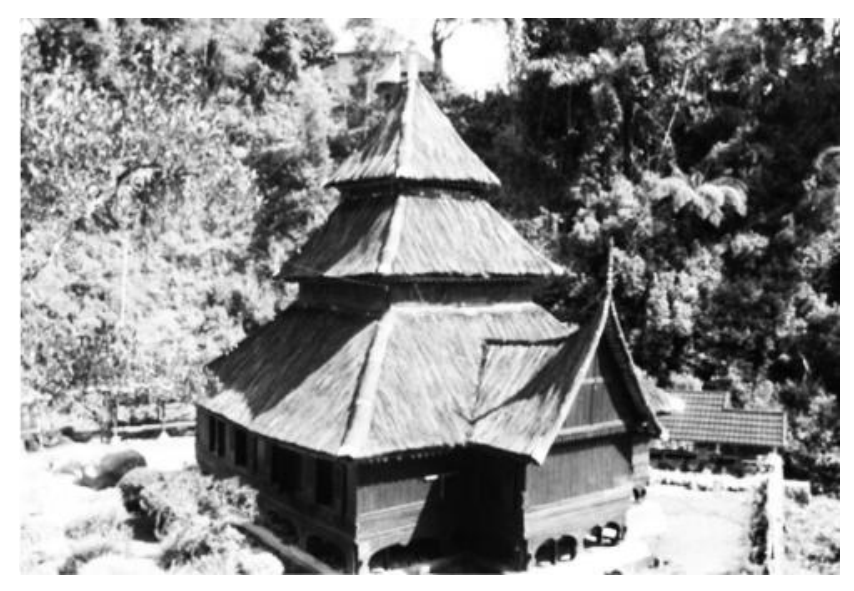

Gambar. 12

Masjid Tuo Kayu Jao Solok

Berdasarkan penuturan dari pengurus masjid (Agus Walrianto 45 tahun) menyatakan bahwa atap tumpang tiga ini merupakan symbol dari imam, khatib dan bilal sekaligus perlambangan tiga kaum yang mendirikan masjid ini yaitu Kayu Aro, Lubuk Selasih dan Kayu Jao. Corak surau dan masjid seperti ini terdapat juga pada Masjid Tuanku Pamansiangan, Koto Laweh Kabupaten Tanah Datar. Hanya saja Masjid Tuo Kayu Jao lebih terawat dan masih mempertahankan atap ijuknya sedangkan Masjid Tuanku Pamansiangan di samping telah berganti atapnya dengan seng, terlihat seperti kurang mendapatkan perawatan dan perhatian dari pemerintah.

Selain pada bagian mihrab, terkadang atap bergonjong dibuatkan secara khusus pada bagian pintu masuk seperti pada Surau Atap Ijuk Nagari Sicincin Kabupaten Padang Pariaman dan Masjid Asasi Nagari Gunung Padang Panjang yang memiliki atap bergonjong pada arah kiblat atau mihrab dan pada dua pintu masuknya.

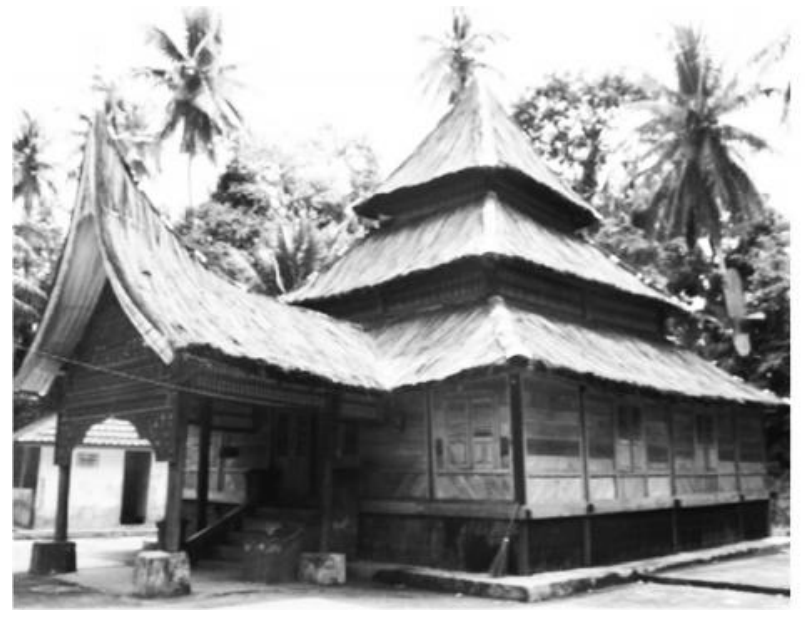

Gambar. 13

Surau Atap Ijuk Sicincin

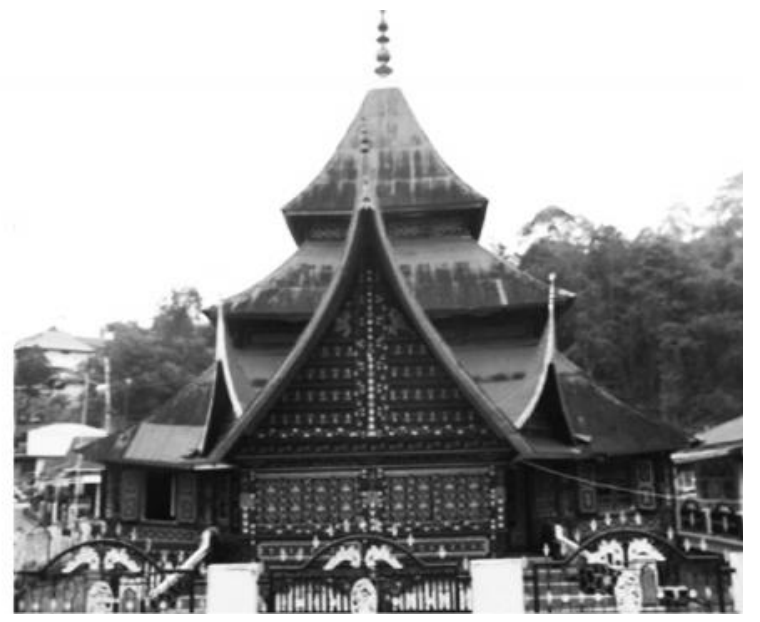

Gambar. 14

Masjid Asasi Nagari Gunung 
Pengaruh nilai-nilai adat dan budaya Minangkabau telah memberikan warna tersendiri terhadap corak surau dan masjid di Minangkabau. Kedua bangunan itu yang pada mulanya sangat kental dengan nuansa Hindunya dimodifikasi dengan nilai-nilai Islam dan adat Minangkabau. sehingga banyak masjid atau surau yang memiliki atap bergonjong seperti pada rumah gadang.

Apabila dilihat dari segi bahan material atap yang dipakai dan digunakan adalah benda-benda yang berasal dari alam berupa ijuk. Namun setelah dilakukan beberapa kali pemugaran karena sulit untuk mendapatkan ijuk maka diganti dengan bahan yang sesuai dengan perkembangan zaman yaitu berupa atap seng atau sejenisnya yang lebih mudah mendapatkan maupun cara pemasangannya dengan tetap menjaga bentuk asalnya. Umumnya masjid-masjid kuno konstruksinya memang berasal kayu baik dinding atapun lantainya. Sedangkan dari sisi penamaan cenderung mengambil sesuatu yang menjadi identitas tempat tersebut dan jarang sekali memakai istilah Arab. Menurut Yunahar Ilyas dalam buku Tiga Sepilin, kalau diberi nama berbahasa Arab ada harapan dan doa dalam nama tersebut, tetapi kalau diberi nama kampung maka seluruh penduduk kampung merasa memiliki dan sekaligus akan bertanggung jawab untuk kemakmuran masjid tersebut (Abidin, 2015; 3)

Selanjutnya corak lain dari tipologi atap tumpang yang berbeda dengan tipologi masjid-masjid yang beratap tumpang lainnnya, ia tidak lagi berbetuk limas tetapi seperti vihara atau klenteng kaum Tionghoa seperti pada Masjid Raya Ganting Kota Padang (didirikan tahun 1805 M).

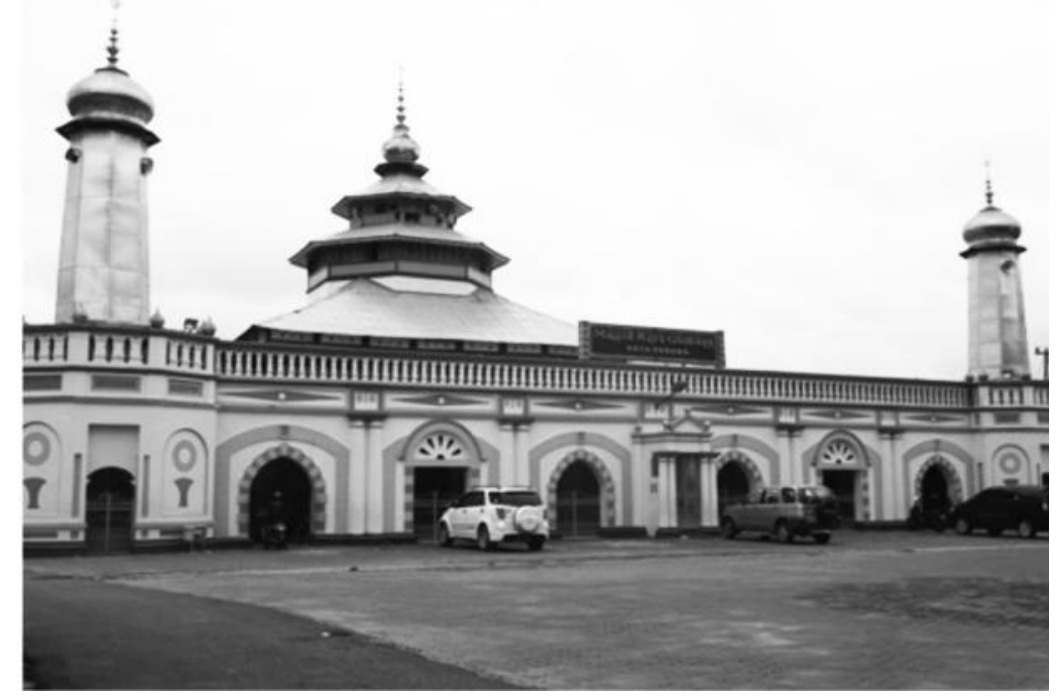

Gambar. 15

Masjid Raya Ganting Kota Padang

Pengaruh Cina terhadap mesjid ini terlihat pada model atapnya yang bertingkat yang berbeda dengan yang lainnya. Atap tumpang pada dua atap paling atas berbentuk klenteng segi delapan. Menurut Graaf dan Piogeud atap bertingkat yang menjadi style masjid-masjid kuno di Minangkabau menyerupai Pagoda di Cina (Harun, 2017:15-16 ). Hal yang seirama dengan itu juga dapat terlihat pada Masjid Raya Kota Pariaman, Masjid Raya Bayur Maninjau dan beberapa masjid yang ada di Kabupaten Padang Pariaman dan Kota Pariaman. 


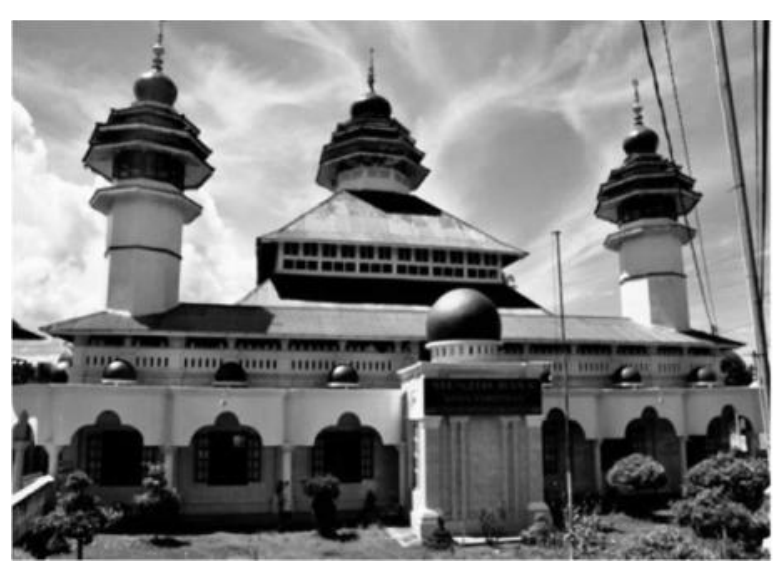

Gambar. 16

Masjid Raya Kota Pariaman

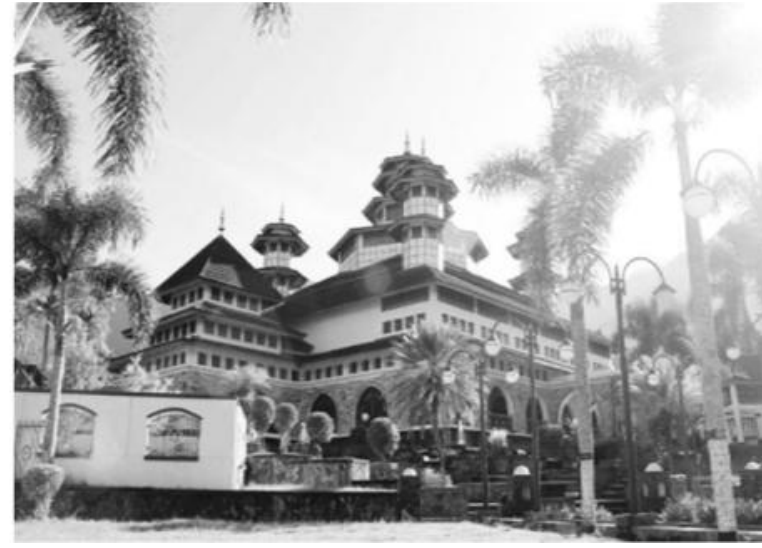

Gambar. 17

Masjid Raya Bayur Maninjau

Seluruh masjid kuno selalu bertumpang tiga sampai lima, semakin keatas semakin kecil dan mengerucut, sedangkan tingkatan yang paling atas berbentuk limas. Tak dapat dipungkiri hal ini merupakan pengaruh Hindu, karena sebelum Islam atap tumpang dipakai untuk kuil, bangunan suci agama Hindu. Atap tumpang sampai sekarang masih lazim dipakai di Bali, namanya meru, dan digunakan khusus mengatapi bangunan-bangunan suci di dalam pura. Pengaruh Hindu ini juga dapat dilihat pada masjid-masjid kuno di pulau Jawa.

Berdasarkan inventarisasi Balai Pelestarian Peninggalan Purbakala Batusangkar, dalam buku yang berjudul Masjid-masjid Kuno di Sumatera Barat, Riau dan Kepulauan Riau yang diterbitkan tahun 2015, jumlah masjid tua yang ada di Sumbar sebanyak 25 unit dan 6 unit diantaranya merupakan surau. Pada umumnya masjid yang ada rata-rata berusia di atas 80 tahun.

\section{Tipologi Atap Kubah}

Tersebar dan berkembangnya Islam ke berbagai daerah dan kawasan diikuti oleh perkembangan dan perubahan dalam corak arsitektur rumah ibadah umat Islam termasuk di Minangkabau. Berbeda dengan corak generasi awal, surau dan masjid pada generasi kedua di Minangkabau memiliki corak atau tipologi atap kubah.

Istilah kubah berasal dari bahasa Arab (qubbah) yaitu atap melengkung setengah lingkaran yang diletakkan sebagai bagian atap bangunan masjid (Sitomorang, 1993: 29). Dalam bahasa Yunani (cupola) mengandung arti rumah tuhan atau dewa. Bangunan kubah sudah ada sejak bangsa Yunani sebelum ditaklukkan bangsa Romawi. Kemudian bangsa Romawi mengadopsi kubah pada bangunan kuil-kuilnya hingga pada istana kaisar. Ketika bangsa Romawi menguasai dunia, mereka membangun istana atau kuil dengan kubah di tanah jajahan, hingga ke Palestina. Selanjutnya kubah diadopsi oleh penganut Yahudi dan Kristen dalam membangun tempat ibadah mereka. Salah satu bentuk kubah masa Imperium Romawi adalah bangunan Pantheon (kuil) di kota Roma.

Penggunaan kubah tercatat mulai berkembang pesat pada periode awal masa Kristen. Salah satu buktinya adalah Hagia Sophia atau Aya Sofya yang pada mulanya adalah gereja berkubah yang dijadikaan masjid pada masa Turki Utsmani oleh Sultan Mehmed II saat menaklukkan Konstantinopel. Kemudian arsitektur Byzantium ini mengilhami corak bangunan masjid zaman Turki Utsmani. 
Dalam sejarah Islam, Masjid Qubbat as-Sakhrah di Yerussalem merupakan masjid pertama yang menggunakan model atap kubah. Semenjak itu banyak bangunan masjid mulai dilengkapi dengan kubah. Kini, kubah seakan menjadi bagian mutlak dan ciri khas sebuah masjid (Rochyim, 1995: 2626). Demikian juga dari sisi bentuk dan model kubah dari masa ke masa terus mengalami perkembangan yang dipengaruhi oleh berbagai faktor. Tidak mengherankan jika bentuk kubah di berbagai belahan dunia mengalami sedikit perbedaaan karena sesuai dengan budaya masyarakat muslim setempat.

Kubah memang bukan berasal dan berakar dari arsitektur Islam secara murni, karena memang ajaran Islam tidak membawa secara langsung tradisi budaya fisik atau Islam tidak mengajarkan secara konkrit tata bentuk arsitektur. Tetapi ia merupakan produk sebuah kebudayaan. Ketika Islam menyebar dan berinteraksi dengan budaya dan peradaban lain, para arsitek Islam tampaknya tidak segan-segan untuk mengambil pilihan-pilihan bentuk yang sudah dimiliki oleh masyarakat setempat tersebut.

Di samping memiliki nilai artistik dan filosofis, kubah memiliki peranan tertentu antara lain dapat berfungsi sebagai penunjuk arah kiblat jika dilihat dari sisi luar, dan menerangi ruang dari dalam. Kemegahan dan indah akan terlihat dari kesan yang ditimbulkan dari kubah masjid. Selain itu, bentuknya yang mengembang di bagian tengah merepresentasikan kelapangan, luas, dan terbuka. Hal tersebut memberikan arti bahwa Islam merupakan ajaran yang terbuka. Di samping merepresentasikan kesan luas bagi orang yang beribadah di dalamnya, kubah memberikan arti kebesaran Tuhan. Terlepas dari makna dan filosofi di dalamnya, kubah memberikan energi positif-religius bagi orang yang beribadah di dalamnya dan menciptakan nuansa yang sakral.

Kubah adalah bentuk bagian atap masjid yang dibuat melengkung seperti separoh bola atau kubah piring (lebih rendah dari kubah separoh bola) atau kubah bawang (karena seperti bawang) dan terkadang pada bagian puncaknya dapat diberi seperti gonjong rumah adat dan terkadang dihiasi dengan lambang bulan sabit. Corak atap kubah pada masjid Minangkabau sangat beragam dan memiliki sejumlah varian antara lain;

Pertama, masjid empat kubah dalam artian bahwa atap berupa kubah pada sebuah masjid berjumlah atau terdiri dari empat buah kubah. Masjid empat kubah merupakan corak atau varian awal dari masjid yang memiliki atap kubah. Masjid empat kubah merupakan corak peralihan dari corak atap tumpang. Apabila corak atap tumpang bahan materialnya pada awalnya didominasi oleh kayu dan ijuk, sedangkan masjid atap kubah menggunakan beton dan seng. Kubah yang merupakan bagian terpenting dari atap yang pada generasi awalnya hanya memiliki jumlah empat buah kubah yang terbuat dari seng.

Masjid empat kubah ini terdiri dari satu kubah besar yang berada pada bagian tengah, sedangkan tiga kubah lainnya yang memiliki ukuran yang lebih kecil berada pada bagian mihrab sebagai pertanda arah kiblat dan dua lainnya berada pada posisi kiri dan kanan bagian depan arah pintu masuk surau atau masjid. Masjid yang memiliki corak empat kubah ini antara lain Masjid Darussalam Kotobaru X Koto Kabupaten Tanah Datar, Masjid Darul Ulya Koto Tinggi, Baso Kabupaten Agam, Masjid Jamik Parabek, Surau Tuanku Syech Aluma, Agam.

Menurut tokoh pemerhati adat Minangkabau (Muhammad Jamil, 50 tahun) saat diwawancarai beliau menuturkan bahwa kubah masjid yang terdiri dari empat buah ini memiliki filosofi bahwa dahulu syarat sebuah nagari di Minangkabau harus memiliki masjid, dan syarat dapat diakui sebagai nagari mesti terdiri dari empat suku atau empat kaum, dan setiap masjid itu mesti memiliki empat unsur yang disebut dengan orang ampek jiniah (empat jenis) yaitu imam (yang bertugas dan bertanggungjawab 
memimpin shalat berjamaah), khatib (yang bertanggungjawab menyampaikan khutbah), bilal (yang bertugas mengumandangkan adzan) dan qadi (yang bertugas menikahkan masyarakat dalam nagari).

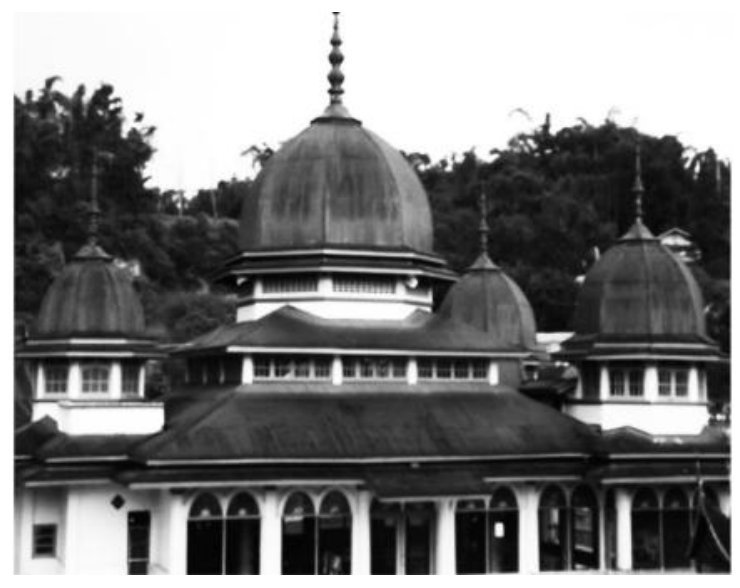

Gambar.18

Masjid Darussalam Kotobaru X Koto

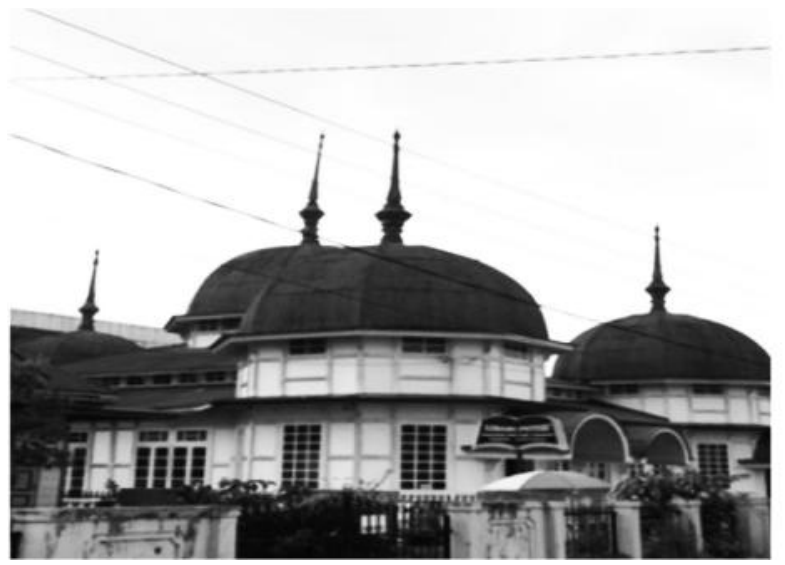

Gambar. 20

Masjid Jamik Parabek

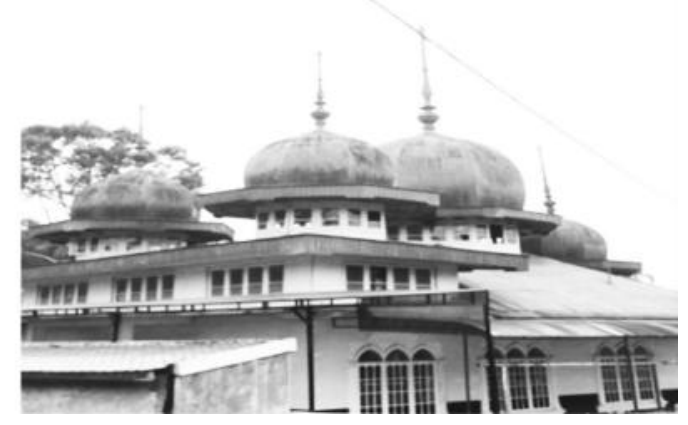

Gambar.19

Masjid Darul Ulya KotoTinggi

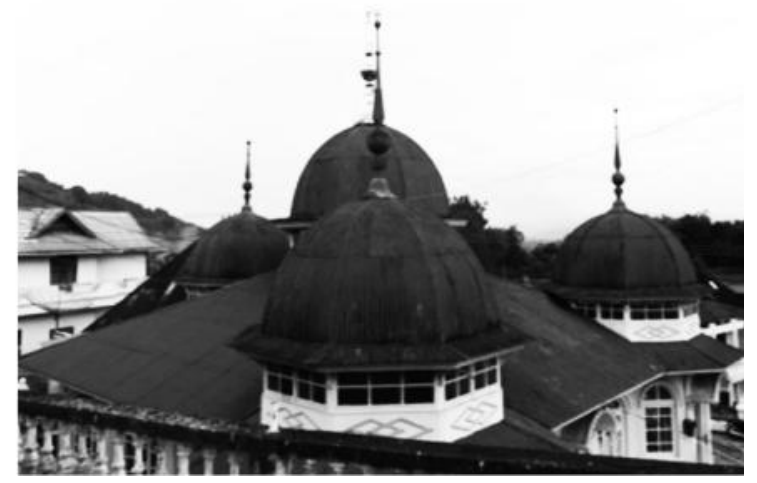

Gambar. 21

Surau Tuanku Syech Aluma

Keempat unsur di atas merupakan perwakilan dari empat suku atau kaum tersebut. Hal ini juga mengisyaratkan dan melambangkan persatuan dalam nagari untuk memakmurkan dan bertanggungjawab secara bersama-sama terhadap keberadaan masjid tersebut. Selain itu, bagi masyarakat Minangkabau secara khsusus dan umat Islam pada umumnya memang banyak hal yang memiliki jumlah empat sehingga orang Minangkabau yang notabene muslim dikatakan mesti taujo nan ampek (tahu dengan yang empat) baik dalam urusan adat maupun urusan agama sehingga itu kemudian dijadikan simbol pada jumlah kubah masjid.

Seiring dengan perkembangan zaman baik dari sisi ilmu pengetahuan maupun teknologi serta Islam mengalami perkembangan yang pesat dan hubungan dengan dunia luar semakin meningkat telah berdampak dan berpengaruh terhadap perkembangan corak seni arsitektur masjid di Minangkabau. Masjid dan surau yang sebelumnya hanya memiliki atap empat kubah berkembang dan berubah menjadi atap lima kubah. Corak ini merupakan lanjutan dari perkembangan dan kelanjutan dari gaya arsitektur masjid zaman sebelumnya. 
Masjid pada generasi ketiga ini memiliki sejumlah perbedaan baik dari segi bentuk, jumlah, ukuran maupun tata letaknya. Masjid ini memilki lima buah atap kubah dengan ciri khas kubah besar terletak pada bagian tengah sebagai kubah utama dan dikelilingi oleh empat kubah lainnya pada keempat sisi masjid secara seimbang dengan ukurannya lebih kecil daripada kubah utama seperti pada Masjid Agung Nurul Islam Kota Sawahlunto, Masjid Jamik Tarok Kota Bukittinggi, Masjid Kotobaru Pangkalan dan masjid lainnya.

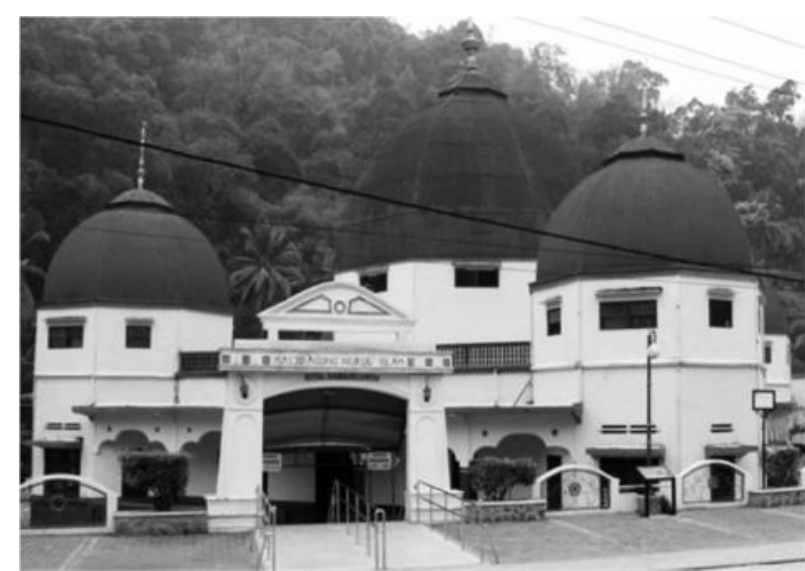

Gambar. 22

Masjid Agung Nurul Islam Sawahlunto

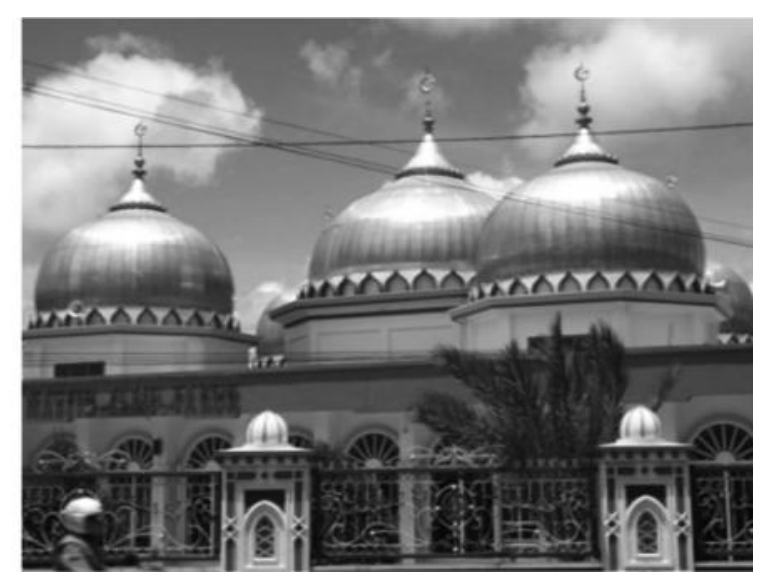

Gambar. 23

Masjid Jamik Tarok Bukittinggi

Masjid-masjid yang memiliki corak lima buah kubah ini mengandung makna dan filosofi yang menggambarkan bahwa rukun Islam itu ada lima dan shalat adalah tiang dari agama maka kedudukan kubah utama bagaikan kedudukan shalat diantara rukun Islam yang lainnya. Selain itu ada juga yang memahami dan memaknai bahwa kubah yang lima itu menggambarkan bahwa umat Islam mendirikan shalat lima waktu dalam sehari semalam.

Seiring dengan perubahan zaman, perubahan dan inovasi terus terjadi sehingga masjid zaman berikutnya tidak lagi memiliki lima atap kubah tetapi memiliki dua corak perubahan yaitu pertama empat kubah yang ada pada setiap sudut depan dan belakang masjid berubah menjadi sebagai menara atau mi' dzanah (tempat pengeras suara adzan) sehingga bangunan empat kubah penyangga tersebut ditinggikan dibanding kubah utama. Hal ini dapat dilihat pada Masjid Agung Tangah Sawah Bukittinggi, Masjid Jihad Tangah Jua Bukittinggi, Masjid al-Azhar UNP Padang, Masjid Quba' Sungai Tarab Kabupaten Tanah Datar dan masjid-masjid lainnya.

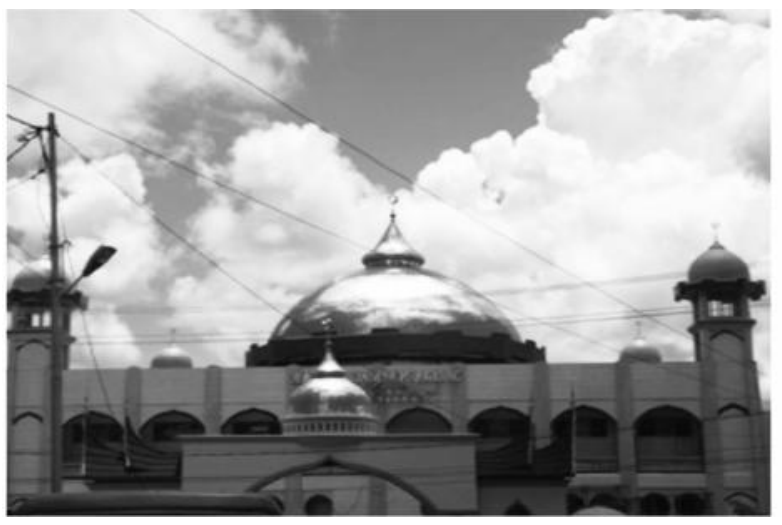

Gambar. 24

Masjid Agung Tangah Sawah

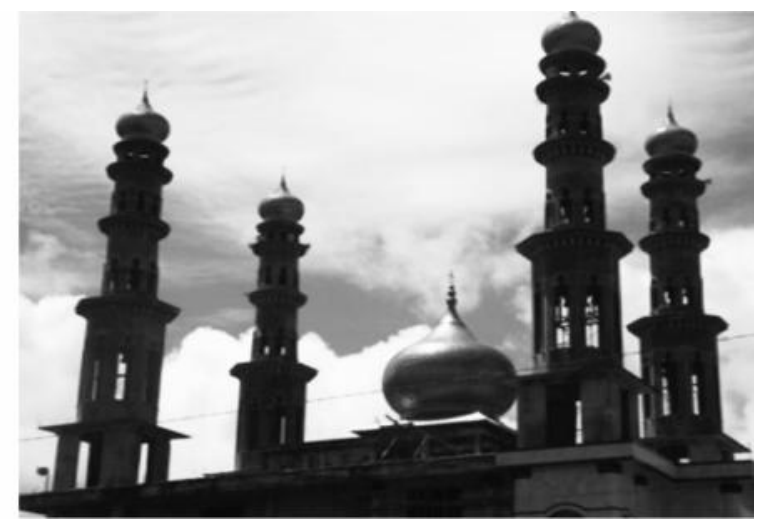

Gambar. 25

Masjid Jihad Tangah Jua 


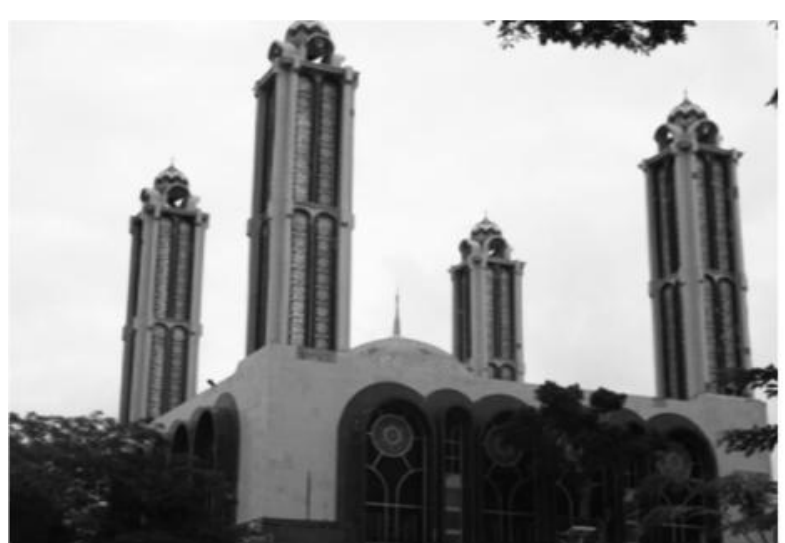

Gambar. 26

Masjid al-Azhar UNP Padang

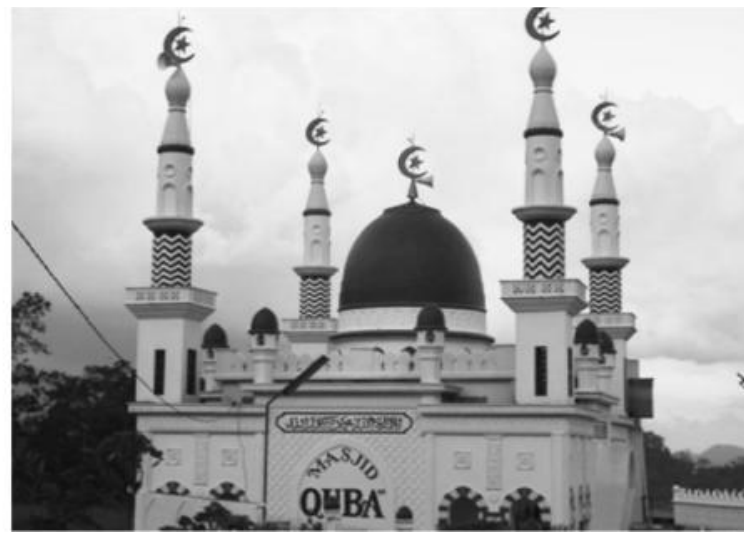

Gambar. 27

Masjid Quba' Sungai Tarab

Bentuk inovasi yang kedua adalah empat kubah penyangga yang mengelilingi kubah utama diinovasi dengan cara menjadikan hanya satu kubah besar dan dihiasi dengan dua menara pada kedua sisinya pada bagian kiri dan kanan arah pintu masuk masjid seperti Masjid Jamik Tigo Baleh Kota Bukittinggi dan Masjid Jamik Panyalaian X Koto Tanah Datar.

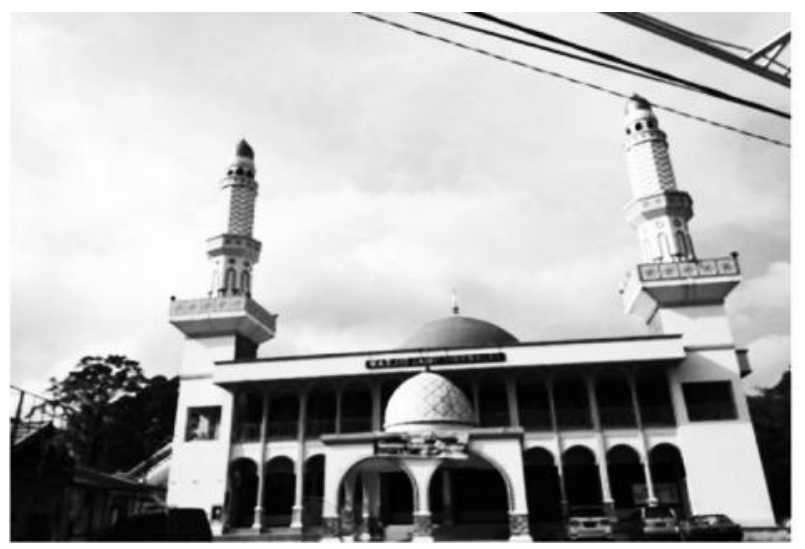

Gambar. 28

Masjid Jamik Tigo Baleh

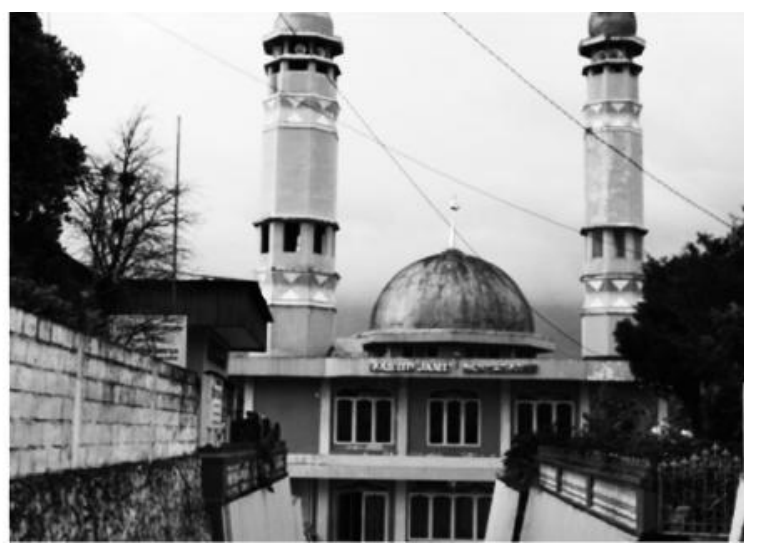

Gambar. 29

Masjid Jamik Panyalaian

Selanjutnya, pada tahapan ini mulai terjadi perubahan dengan corak pemisahan antara masjid yang satu kubah sebagai bangunan utama dengan menara sebagai bangunan pendamping. Corak ini sangat lazim ditemukan seperti masjid al-Amin Pagaruyung. Bahkan ada juga yang hanya menjadikan satu kubah besar saja tanpa menara seperti yang terdapat pada Masjid Rahmatan lil Alamin Komplek Universitas Pendidikan Indonesia Padang, Masjid Jamik Aur Kuning, Masjid Raya Limo Suku Sungai Pua, Agam dan lain-lain.

Berdasarkan uraian di atas dapat diklasifikasikan bahwa corak seni arsitektur Islam Minangkabau berupa surau dan masjid memiliki dua tipologi yaitu tipologi atap tumpang dan tipologi atap kubah. Masing-masing dari kedua tipologi tersebut memiliki sejumlah varian dan sebagiannya dikembangkan dengan gaya arsitektur yang lebih modern. Kombinasi atap kubah dengan menara lebih modern dapat ditemukan pada Masjid Raudhatul Jannah Kota Bukittinggi (didirikan tahun 2012 M) dan Masjid Baiturrahmah Kota Padang (didirikan tahun 2015 M). 


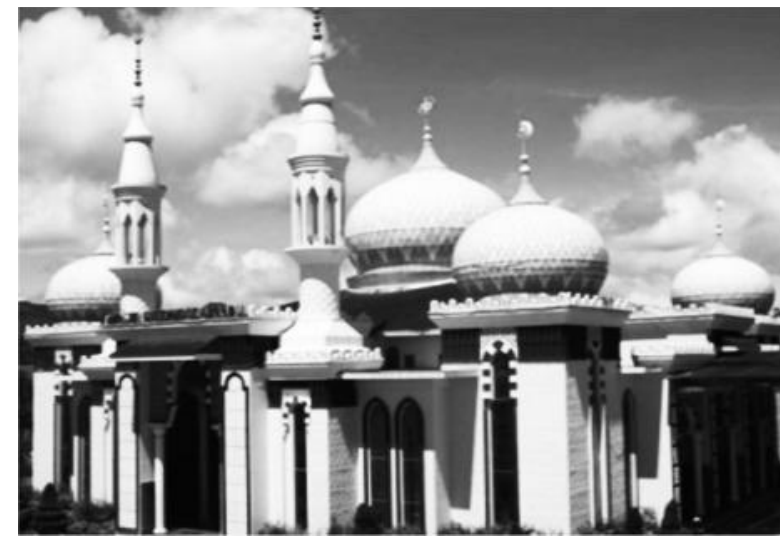

Gambar. 30

Masjid Raudhatul Jannah Bukittinggi

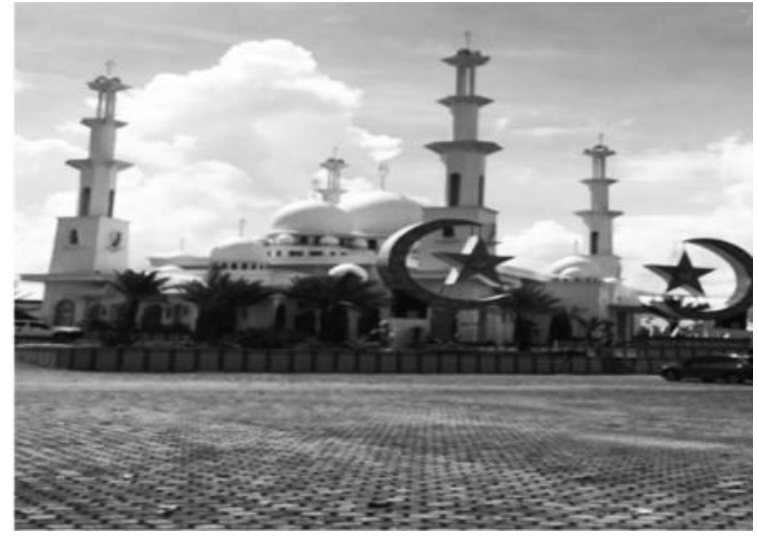

Gambar. 31

Masjid Baiturrahmah Padang

Adapun corak atap bergonjong bentuk perpaduan antara Islam dan adat Minangkabau yang lebih modern dapat terlihat pada Masjid Raya Sumatera Barat (didirikan tahun 2007 M).

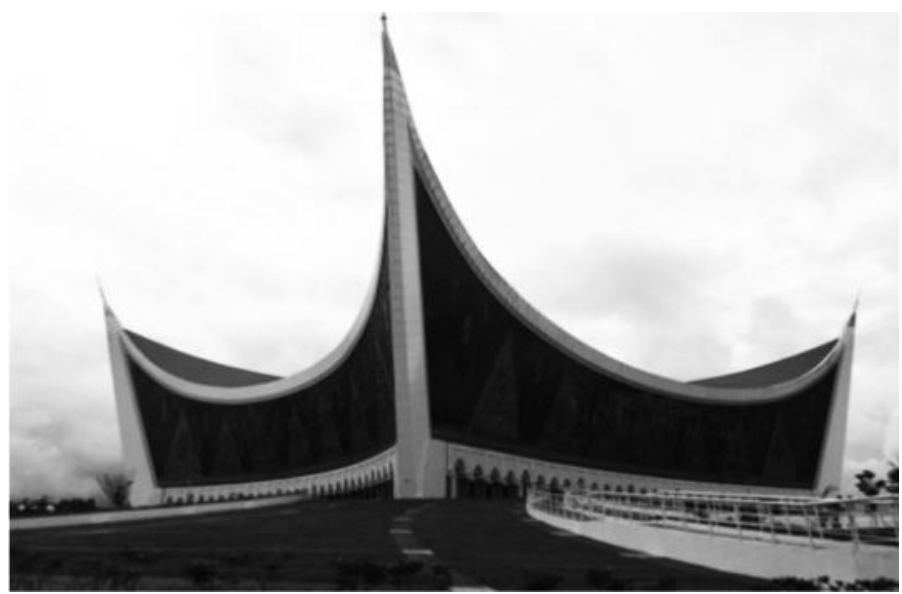

Gambar. 32

Masjid Raya Sumatera Barat

Masjid tipologi atap kubah yang terdapat pada gaya arsitektur Masjid Raudhatul Jannah Bukittinggi dan Masjid Baiturrahmah Padang sangat kental dengan corak khas timur tengahnya. Kedua masjid ini memadukan antara atap kubah yang dikombinasi dengan menara yang menyatu pada bangunan masjid itu. Berbeda halnya dengan Masjid Raya Sumatera Barat yang mengikuti tipologi arsitektur Minangkabau dengan ciri bangunan berbentuk gonjong yang memiliki empat sudut lancip yang mirip dengan desain atap rumah gadang dan seperti bentuk bentangan kain jika dilihat dari atas. Gaya arsitektur ini memiliki filosofis yang melambangkan seperti bentangan kain yang digunakan empat kabilah suku Quraisy (Alimin : 2016 : 88) ketika berselisih pendapat tentang siapa yang berhak memindahkan batu Hajar Aswad di Kota Mekkah. Pada saat itu nabi SAW memberikan kesempatan kepada setiap kabilah tersebut untuk memegang dan mengangkat hajar aswad tersebut pada keempat sisinya. Hal ini juga menjadi lambang dan simbol persatuan umat Islam. 


\section{PENUTUP}

Surau dan masjid merupakan dua model seni arsitektur Islam yang paling populer di Minangkabau yang memiliki corak yang beragam semenjak zaman sebelum kemerdekaan dan pasca kemerdekaan sampai saat ini. Corak itu dapat diklasifikasikan menjadi dua tipologi yaitu tipologi atap tumpang dan tipologi atap kubah yang sama-sama memiliki sejumlah varian.

Tipologi atap tumpang pada umumnya ditemukan pada masjid atau surau zaman klasik yang bersifat tradisional yang merupakan perkembangan awal Islam di Minangkabau dengan ciri khas atap ijuk. Namun, sekarang tidak semua masjid atau surau tersebut dapat mempertahankan atap ijuk tersebut karena tingkat kesulitannya baik dari sisi untuk mendapatkan bahan materialnya maupun tukang yang akan memasangkannya, sehingga telah banyak yang beralih ke atap seng. Masjid atau surau ini pada umumnya berdiri pada tahun 1800-an atau sebelumnya yang memiliki nilai sejarah tersendiri sehingga dilindungi dan dipelihara oleh Balai Pelestarian Cagar Budaya Propinsi Sumatera Barat yang sampai saat ini diantaranya ada yang masih dipakai untuk umum dan sebagian lainnya telah ditutup untuk umum. Adapun tipologi atap kubah merupakan masjid generasi kedua di Minangkabau setelah generasi atap tumpang. Pada umumnya masjid ini memiliki bahan material atap berupa seng, namun sebagian ada yang telah berubah mengikuti perkembangan zaman sehingga ada yang telah beralih kepada material beton atau jenis lainnya.

Corak arsitektur kedua tipologi ini sangat kental dipengaruhi oleh adat dan budaya Minangkabau yang memiliki nilai estetis-filosofis tersendiri. Corak seni arsitektur Islam Minangkabau ini terus mengalami perkembangan dari masa ke masa sesuai dengan perkembangan iptek dan akulturasi budaya Islam lainnya.

Bentuk arsitektur rumah ibadah umat Islam dapat saja memiliki bentuk yang beragam dan mengadopsi budaya luar Islam sekalipun karena memang Islam tidak mengaturnya secara langsung, tetapi ia adalah produk kebudayaan. Corak surau atau masjid yang selalu berubah dapat dilatarbelakangi oleh beberapa faktor seperti faktor agama, alam, budaya, ilmu pengetahuan, teknologi serta ruang dan waktu sehingga selalu terbuka kesempatan untuk berkreasi dan berinovasi. Masih banyak sisi lain dari seni arsitektur Islam yang perlu untuk diteliti termasuk sisi lain dari surau dan masjid di Minangkabau. Diharapkan ada penelitian lanjut untuk menyempurnakan penelitian ini.

\section{DAFTAR PUSTAKA}

Abidin, Mas'oed. 2016. Tiga Sepilin Surau Solusi untuk Bangsa. Yogyakarta: Gre Publishing. Alimin, Nurhayatu Nufut. "Masjid Raya Sumatra Barat Sebagai Simbol Persatuan Muslim di Sumatra Barat" dalam Invensi, Vol. 1, No. 1. Juni 2016.

Azra, Azyumardi. 2003. Pendidikan Islam Tradisional Dalam Transisi Dan Modernisasi. Jakarta: PT. Logos Wacana Ilmu.

BPCB sumbar. 2017. Masjid Raya Bingkudu. https://kebudayaan. kemdikbud.go.id/bpcbsumbar/ masjid-raya-bingkudu/. Diakses pada tanggal 14 Juli 2018.

Fanani, Achmad. 2009. Arsitektur Masjid. Yogyakarta: Bentang.

Gilang Aditya. 2018. Keunikan dalam Sebuah Bangunan Cagar Budaya "Masjid RaoRao" https://kebudayaan.kemdikbud.go.id/bpcbsumbar/keunikan-dalam sebuah-bangunancagar-budaya-masjid-rao-rao/. Diakses 10 September 2018. 
Hanani, Silfia. 2003. Surau Aset Lokal Yang Tercecer. Bandung: Humaniora Utama Press Harisman. 2001. Ukiran Masjid Tradisional Minangkabau di Tanah Datar, Propinsi Sumatera Barat: Kajian Bentuk, Fungsi dan Makna. Tesis, Program Pascasarjana Universitas Udayana, Denpasar.

Harun, Maidir. 2017. Sejarah Rumah Ibadah Kuno di Kota Padang. Padang: IAIN Imam Bonjol Press.

Hasan, Hasmurdi. 2004. Ragam Rumah Adat Minangkabau: Falsafah, Pembangunan dan Kegunaan. Jakarta: Yayasan Citra Pendidikan Indonesia.

Husain, Huri Yasin. 2007. Fikih Masjid. Jakarta: Pustaka Al-Kautsar.

Ilham, Muhammad. 2010. Masjid Minangkabau dalam Lanskap Foto Zaman Kolonial Belanda. http://ulama-minang.blogspot.com/. Diakses pada tanggal 20 Maret 2018.

Indrayuda, Muasri. dkk, 2013. Randai Suatu Aktivitas Kesenian dan Media Pendidikan Tradisional. Padang: Dinas Kebudayaan dan Pariwisata Provinsi Sumatera Barat UPTD Taman Budaya.

Irawati, M. Johan. 2009. "Peran Arkeologi dalam Kajian Nusantara", dalam Jurnal Lektur Keagamaan, Puslibang Lektur Keagamaan, Badan Litbang dan Diklat, Kementerian Agama RI, Vol. 7, No. 1. Tahun 2009.

MS, Amir. 2007. Adat Minangkabau; Pola dan Tujuan Hidup Orang Minang. Jakarta: PT Mutiara Sumber Widya.

Oktavianti, Apriliya. 2018. Masjid Saadah Sumatera Barat. https://situsbudaya.id/masjid-saadahkabupaten-tanah-datar-sumatera-barat/ Diakses pada tanggal 20 Agustus 2018.

Rochym, Abdul. 1995. Mesjid Dalam Karya Arsitektur Nasional Indonesia. Bandung: Penerbit Angkasa.

Samad, Duski. 2002. Syeikh Burhanuddin dan Islamisasi Minangkabau. Padang: The Minangkabau Foundation.

Shihab, Muhammad Quraish. 1996. Wawasan al-Qur'an. Bandung: Penerbit Mizan.

Situmorong, Oloan. 1993. Seni Rupa Islam Pertumbuhan dan Perkembangannya. Bandung: Angkasa.

Tim Penyusun. 2008. Metode Penelitian Arkeologi: Metode Analisis Arsitektur. Batusangkar: Balai Pelestarian Peninggalan Purbakala Wilayah Kerja Propinsi Sumatera Barat, Riau, dan Kepulauan Riau.

Wiryoprawiro, Zein M. 1986. Perkembangan Arsitektur Masjid di Jawa Timur. Bandung: PT Bina Ilmu.

Yudoseputro, Wiyoso. 1986. Pengantar Senirupa Islam di Indonesia. Bandung: Angkasa.

Zainuddin. 2013. “Arsitektur Masjid Lima Kaum Batusangkar”, Jurnal Lektur Keagamaan, Vol. 11, No. 2, Tahun 2013.

Zein, Abdul Baqir. 1999. Mesjid-Mesjid Bersejarah di Indonesia. Jakarta: Gema Insani Press. 